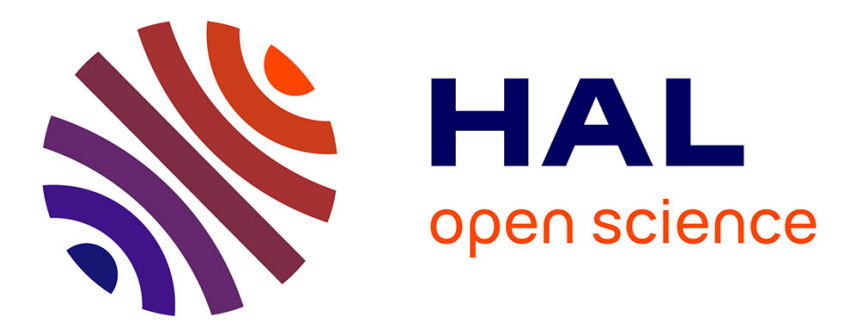

\title{
Late Holocene swampy forest of Loango Bay (Congo). Sedimentary environments and organic matter deposition
}

\author{
Dieudonné Malounguila-Nganga, Pierre Giresse, Mohammed Boussafir, \\ Timothée Miyouna
}

\section{To cite this version:}

Dieudonné Malounguila-Nganga, Pierre Giresse, Mohammed Boussafir, Timothée Miyouna. Late Holocene swampy forest of Loango Bay (Congo). Sedimentary environments and organic matter deposition. Journal of Asian Earth Sciences, 2017, 134, pp.419-434. 10.1016/j.jafrearsci.2017.05.022 . insu-01540211

\section{HAL Id: insu-01540211 \\ https://hal-insu.archives-ouvertes.fr/insu-01540211}

Submitted on 26 Jun 2017

HAL is a multi-disciplinary open access archive for the deposit and dissemination of scientific research documents, whether they are published or not. The documents may come from teaching and research institutions in France or abroad, or from public or private research centers.
L'archive ouverte pluridisciplinaire HAL, est destinée au dépôt et à la diffusion de documents scientifiques de niveau recherche, publiés ou non, émanant des établissements d'enseignement et de recherche français ou étrangers, des laboratoires publics ou privés.

\section{(1) $(1) \Theta$}

Distributed under a Creative Commons Attribution - NonCommercial - NoDerivatives 44.0 


\section{Accepted Manuscript}

Late Holocene swampy forest of Loango Bay (Congo). Sedimentary environments and organic matter deposition

Malounguila-Nganga Dieudonné, Giresse Pierre, Boussafir Mohammed, Miyouna Timothée

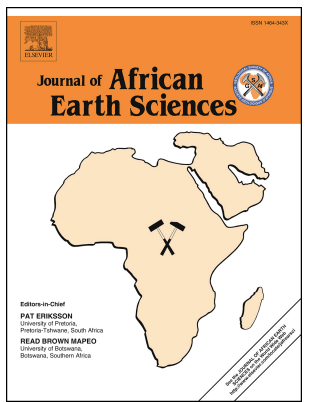

PII: S1464343X17302595

DOI: 10.1016/j.jafrearsci.2017.05.022

Reference: AES 2926

To appear in: Journal of African Earth Sciences

Please cite this article as: Malounguila-Nganga Dieudonné, Giresse Pierre, Boussafir Mohammed, Miyouna Timothée, Late Holocene swampy forest of Loango Bay (Congo). Sedimentary environments and organic matter deposition, Journal of African Earth Sciences (2017), doi: 10.1016/ j.jafrearsci.2017.05.022

This is a PDF file of an unedited manuscript that has been accepted for publication. As a service to our customers we are providing this early version of the manuscript. The manuscript will undergo copyediting, typesetting, and review of the resulting proof before it is published in its final form. Please note that during the production process errors may be discovered which could affect the content, and all legal disclaimers that apply to the journal pertain. 


\title{
Late Holocene swampy forest of Loango Bay (Congo).
}

\section{Sedimentary environments and organic matter deposition}

Malounguila-Nganga Dieudonné ${ }^{1}$, Giresse Pierre ${ }^{2}$, Boussafir Mohammed ${ }^{3}$ and Miyouna Timothée ${ }^{1}$

\author{
${ }^{1}$ Marien Ngouabi University, Geology Department, Brazzaville, Congo \\ ${ }^{2}$ Perpignan Via Domitia University, CEFREM, UMR 5110 CNRS, 66860 Perpignan, France \\ ${ }^{3}$ Orléans University, ISTO Laboratory, UMR 6113 CNRS, 45000 Orléans, France
}

\section{Abstract}

This region, comprised between the Kouilou estuary and Pointe-Noire, is characterised by a very specific morphological setting. On the continental side, the coastal sector is dominated by cliffs of sand over 100 metres high, referred to as the Série des Cirques, whereas, on the ocean side, very active erosion is presently taking place which has resulted in a retreat of the shoreline of more than $100 \mathrm{~m}$ over the last hundred years.

New ${ }^{14} \mathrm{C}$ datings and different analyses of organic matter and clay minerals (X-Ray data) were performed in order to reconstruct the geological and ecological evolution of the area during the Late Holocene and replace it in the palaeoclimatic scheme deduced from previous regional studies.

From 7-6000 yr cal BP, the accumulation of important beach barriers by the oceanic drift allowed the definition of a narrow swamp depression several tens of kilometres long. A dense ombrophile and hydromorphic forest, in spite of being very close to the oceanic coast, remained sheltered from any brackish influence and fed accumulations of peat and organic muds. The emersive trend of $3000-2000 \mathrm{yr} \mathrm{BP}$, i.e. the passage from a vast forest swamp with a water body several metres deep to a wet zone with some emersions, is expressed by a large colluvial accumulation. 
High primary production is not clearly attested in this wet area. High $\mathrm{HI}$ values would indicate rather long-lasting conservation in a swampy environment, the lowest values indicating alternating episodes of emersion and immersion. In such peatlands, OM preservation is favoured by an anoxic environment and rapid burial.

The $\delta{ }^{13} \mathrm{C}$ values of older peats dated ca. $7000 \mathrm{yr}$ cal BP are -28 to $-26 \%$, typical of a C3 origin. Thus, the ca. $-16 \%$ ovalue indicates the greatest opening of the cover, suggesting a forest-savanna mosaic ca. $2500 \mathrm{yr}$ cal BP. At Kivesso, several proxies suggest a wetter trend towards $500 \mathrm{yr}$ cal BP. An ultimate drier trend is observed during the last two centuries, which has been attested to by a $\delta{ }^{13} \mathrm{C}$ ratio indicating a clear decrease of the forest extent, probably linked to local Kivesso edaphic conditions.

\section{Keywords}

Congo, Late Holocene, sedimentology, organic matter, $\delta{ }^{13} \mathrm{C}$, pyrolysis

\section{Introduction}

In recent years, various lakes and swamps have been studied repeatedly, providing comprehensive reconstructions of tropical rainforest changes over the last millennia, throughout Central Africa (Vincens et al., 2000) and even beyond (Maley, 1997; Maley, 2012; Bostoen et al., 2015)).

Palaeoenvironmental data indicate that a climate crisis affected the Central African forest block during the Holocene, first on its periphery, around $4000 \mathrm{BP}$, and later at its core, around 2500 BP (Bostoen et al., 2015). In a more regional area, Vincens et al. (1999) provided a composite comparison of forest response to climatic changes during the last five thousand years in western Central Africa. During the mid-Holocene period (ca. 5-4000 yr BP), the forest cover was largely extended and probably much more developed than it is today. The area least favourable to forest extent, the Niari valley with low precipitation, currently 
covered by savannas, was occupied between 5300 and 4000 yr BP by semi-deciduous forests. After the drying of Lake Sinnda, grasslands remained the dominant cover, seasonal water stress allowed a weak forest recovery from ca. $1000 \mathrm{yr} \mathrm{BP}$ and a brief dry event occurred again around 700 yr BP (Vincens et al. 1994).

By contrast, the rainy site of Lake Kitina shows a recovery of the forest cover during the last two thousand years. Slight changes are recorded around $1500 \mathrm{BP}$, later followed by the resumption of the enclosed savanna after 500-600 BP (Elenga et al., 1996). On the Congolese coast and in the Bateke region, with both medium rainfall and active drainage through sandy soils, the savanna maintained itself more or less up to the present time, although a short-lived moist episode occurred around 1500 yr BP, while present-day climatic conditions began around 500-600 yr BP (Schwartz et al., 1990; Elenga et al, 1992).

During the last few decades, various Holocene swampy soils and deposits of the Congolese coast were studied either in an outcropping position, such as in Loango and Pointe-Indienne, or buried under recent sands of the offshore bar, as in the Kouilou and Songololo estuaries (Delibrias et al., 1973; Giresse and Kouyoumontzakis, 1974; Giresse and Moguedet, 1982; Schwartz, 1985; Dechamps et al, 1988; Elenga, 1992; Elenga et al., 1992). A wet episode of swampy forest with Monopetalanthus is observed between 5800 and $3100 \mathrm{yr}$ BP. After 3100 yr BP, pollen studies suggest a marked opening of the forest and an extension of emerged lands and hydromorphic soils. On the scale of the last centuries, several Congolese sites suggest increasing erosion (Giresse and Moguedet, 1982; Elenga et al., 1996; Elenga et al., 2001).

Presently, under the action of oceanic erosion, numerous new outcrops have recently appeared in the Bay of Loango, located 20 km north of Pointe-Noire (Fig. 1). Such occurrences provide an approach for a new and much broader Holocene history of the continental environments close to the shoreline. As they are in an outcropping position, they permit an extended and direct observation of the lateral facies transition that cannot be carried out by soundings alone.

On the basis of ${ }^{14} \mathrm{C}$ AMS datings, a new sedimentary facies study of this specific 
morphological setting is proposed. Its aim is to substantially deepen and revise the previous studies based on a restricted number of sedimentary sequences. The study will be completed by geochemical analyses of the organic matter that is very highly concentrated in several black layers or several brown soils horizons and which had only been characterised in a fragmentary way.

\section{General setting}

A $1000-\mathrm{km}$-long N-S trending range, the Mayombe mountain range, separates the Congo Basin from the western flank of the basin. Seaward of these mountains, Cenozoic nonmarine sedimentary rocks occur on the lower slope of the African Surface Basin. These deposits, like the 'Continental Terminal', are likely to have developed after the upwarping of Africa's swell ca. $30 \mathrm{Ma}$ (Burke and Gunnel, 2008). The upper $200 \mathrm{~m}$ of deposits are coloured clays and sands formations called 'Série des Cirques'. This series shows erosion forms in circuses that cut it at rather important depths, as in the Cirque of Diosso, letting appear a succession of alternating layers of sand and clay, which through lateritisation range in colour from yellow to pink to dark red (Hourcq, 1966).

This fossil-less series is dated as 'Plio-Pleistocene' by analogy with the Benin Sands of Nigeria (Cosson, 1955). Most quartz grains indicate a wind imprint (arcuate cracks) that can be widely erased by later water action, some of which are coated in a secondary siliceous film. The character and the alternation of beds evoke a continental sedimentation in fluviolacustrine closed ponds (Cosson, 1955; Massengo, 1970; Giresse et al., 1981). There is no evidence of Quaternary marine deposits above the current oceanic zero. The Holocene sea reached the current level approximately 6000 years ago and has never overtaken it since (Delibrias et al., 1973).

As a general process going from Luanda to Cape Lopez, this coast is fed by very a powerful southwestern littoral drift. At the levels of Pointe-Noire and Port-Gentil harbours, the important northward sand transit reaches 300,000-400,000 m³/year (Bourgoin et al, 1963). Sandy barriers constitute two, even three alignments, which can reach 10-15 m in height. Wind accumulation stemming from the deflation of the beach expresses a seaward highstand 
progradation (Giresse and Kouyoumontzakis, 1974).

The coastal plain consists of a slowly rising undulating plateau rising from sea level to heights of 150 to $170 \mathrm{~m}$. To the north of the bay, the bank of the plateau is very close to the ocean, at Diosso, where cliffs rise to 20 or $30 \mathrm{~m}$ above the sea level. The plateau is intersected by river valleys and recent steep erosion gullies. The short rivers draining the hillsides of the Série des Cirques are called loubende, meaning dirty or shady waters. The best known is the Red River (Matoubi River), which acts as the main drainage channel of the Pliocene-Pleistocene Diosso Gorges. Its bed is sometimes blocked by poorly compacted sediment packages originating from the nearby cliff. The wideness of the valleys of these loubende may indicate past flows that were more effective than the current ones.

Soils are commonly ferralitic and psammitic (ferralic arenosols) with up to $95 \%$ sand content, while hydromorphic soils and podzols are restricted to the wettest areas. The podzol upper horizon is strongly leached and its white colour characterises a very wide surface of the littoral band (Jamet and Rieffel, 1975). The real age of the beginning of the podzol process could be of the order of 3000-3500 yr BP (Schwartz, 1985; Elenga et al., 1992).

\section{Material and Methods}

The Loango Bay shows a low coast lined with barrier beaches, except near Pointe Indienne where the Série des Cirques cliff approaches the coastline (Fig. 1). Locally, the progress of oceanic erosion affected the lowermost horizon of podzolic soils and different swampy forest organic deposits developed directly on the sands of the Série des Cirques.

The Loango site, with three studied sections (Loango South, Loango North 1 and 2), corresponds to Pointe-Indienne, the convex shape of which is due to the Lower Senonian fine sandstone forming cuesta above Turonian marls (Cosson, 1955; Giresse and Tchikaya, 1975). 1500 m further east, the North Loango 1 and 2 sections lies in the axis of a small palaeovalley, the limits of which are suggested by those of the organic soils (in blue, Fig. 2). The site of Kivesso is located at the foot of the erosion cliffs of the Série des Cirques, the 
most spectacular "cirque" being the Gorges of Diosso. The five studied sections of Kivesso (KVS3, KVS4, then KVS5, KVS6 and KVS7) are located in the two northernmost kilometres (Fig. 1 and 3).

Studies of these eight selected sections are presented here on the scale of the sedimentary layers and pedological horizons successions (Fig. 1, 2, 3). Before sampling, the sections were described and the facies identified on the basis of their colour, lithology and sedimentary structures. Sediments were then sampled at some $10 \mathrm{~cm}$ intervals. After wet sieving, the $>50 \mu \mathrm{m}$ sandy fraction was examined with a stereo microscope. Various markers of distinctive soil profiles were recognised: ochre-stained quartz, white quartz, oxidised debris, black vegetal debris. Images were obtained using the Scanning Electron Microscope (SEM) coupled with an Energy dispersive Tracor Microscope to study the nanostructures and composition of selected particles. Clay minerals were determined using a Philips R.X diffractometer.

In a first step, organic carbon and nitrogen contents were evaluated, respectively using the coulometer and Kjedahl method. Then, pyrolysis measurements were carried out with 100 mg of powder sample using a Turbo' Rock-Eval 6 pyrolyser. The Total Organic Carbon (TOC), hydrogen index $(\mathrm{HI})$ and oxygen index (OI) were calculated with the amounts of hydrocarbon compounds $(\mathrm{HC}), \mathrm{CO}$, and $\mathrm{CO}_{2}$ resulting from thermal cracking of the organic matter (OM), between well-defined temperature limits (Espitalié et al., 1985). It results that TOC (in wt.\%) is the sum of all the organic carbon components $\left(\mathrm{HC}, \mathrm{CO}\right.$, and $\left.\mathrm{CO}_{2}\right)$. TpS2 (in ${ }^{\circ}$ ) is the corrected temperature of the oven, w hich corresponds to the optimum $\mathrm{HC}$ release. $\mathrm{HI}$ and $\mathrm{Ol}$ are the most significant parameters of the pyrolytic analyses. $\mathrm{HI}$ (in $\mathrm{mg}$ $\mathrm{HC} / \mathrm{g} \mathrm{TOC}$ ) corresponds to the quantity of $\mathrm{HC}$ released relative to $\mathrm{TOC}$, and is correlated to the $\mathrm{H} / \mathrm{C}$ ratio. $\mathrm{Ol}$ (in $\mathrm{mg} \mathrm{O}_{2} / \mathrm{g} \mathrm{TOC}$ ) corresponds to the quantity of oxygen released as $\mathrm{CO}$ and $\mathrm{CO} 2$, relative to $\mathrm{TOC}$, and is correlated to the $\mathrm{O} / \mathrm{C}$ ratio.

The $\delta^{13} \mathrm{C}$ isotopic signatures were measured in the CEFREM (Perpignan University) with an elementary analyser coupled with an Isoprime (GVI) IR-MS mass spectrometer. Samples compositions were reported using the standard d-notation with respect to the Vienna Pee 
Dee Belemnite (PDB) standard. Isotopic results were obtained with uncertainties of \pm 0.151 . Every time the available quantities of material allowed it, three measures were carried out on every sample and the mean value was calculated.

Black levels with high organic matter (OM) content were selected for accelerator mass spectrometer (AMS) age dating. ${ }^{14} \mathrm{C}$ analyses were carried out at the Radiocarbon Laboratory in Posnan, Poland. Calibration into calendar scales was calculated using the northern hemisphere calibration curve (software Calib 5.0.2) (Stuiver and Reimer, 1993). Calendar ages are given with a $68 \%$ range (Table 1). Datings obtained by previous authors were frequently recorded and indicated in conventional ${ }^{14} \mathrm{C}$ ages BP. We had to respect this first presentation as we did not always obtain the necessary information to proceed to the calculation of the calendar ${ }^{14} \mathrm{C}$ ages.

\section{Lithology and dating, results}

\subsection{Loango sector (Fig.2)}

South Loango. Above the Senonian greyish siltstone, the Holocene cover is $2.5 \mathrm{~m}$ thick. The first deposit is $20-\mathrm{cm}$-thick greenish clayey sand including white, dulled or mat quartz grains. This sand is characterised by poor sorting. Several white siliceous fragments with a conchoidal break testify to the reworking of the silicified limestone of the nearby Eocene roof (Hourcq, 1966). This deposit is covered by greyish silty sand including some clayey lenses. Above, a brownish, fine-grained level becomes coarser toward the top, where it is associated with iron concretions. The successive thin layers in the lower part of the section allowed us to obtain three ${ }^{14} \mathrm{C}$ ages in good stratigraphic coherence on successions some $10 \mathrm{~cm}$ thick: 7205 cal yr BP (rods), 6846 cal yr BP (black debris) and 4710 cal yr BP (black debris) (Fig. 2 and 5, Table 1). Then, around one metre of fine and well-sorted white sand forms the top of the section.

North Loango 1. The whole thickness of the exposed cover is about $5 \mathrm{~m}$; however, the Senonian bedrock was not reached. The section begins with a 1.5-m-thick leached, white, 
and well-sorted sand similar to the top of the South Loango section. Above one metre of ochre-brown laminated silt is covered by $0.5 \mathrm{~m}$ of organic fine-grained deposit, the top of which was dated at 2516 cal yr BP (Fig. 2 and 5, Table 1). The poorly sorted sandy fraction is a mixture associating blunt-shining and blunt-frosted quartz grains, grains of white silica, and numerous ilmenites. The upper part is formed by five successive graded microsequences of ochre deposits with a sandy lower term and a finer (silts and clay) upper term. The accumulation ends with a $0.8 \mathrm{~m}$ layer of medium sand.

North Loango 2. The lower part of the section allows us to observe nearly the whole podzolic soil sequence: the dark iron pan is covered by over two metres of leached white sand and the humiferous horizon was preserved. However, the Senonian bedrock was not reached. Upward, some ten centimetres of silty laminae cover clayey medium sands, with poor OM content. The last deposit is restricted to a single graded sequence with current ridges and ilmenite-rich laminations. The section ends with nearly one-metre-thick ochre to yellow ochre and medium-to-coarse sand with no evidence of grading.

The $\mathrm{C}$ org content of the flood sequences could be measured only in the upper part of the section, the richest microbeds ranging between 0.18 and $0.45 \%$, while the $\mathrm{C} / \mathrm{N}$ ratio varied from 7.2 to 10 (Table 2).

\subsection{Kivesso sector (Fig. 3)}

KVS 7. This outcrop, like the others of this site, is located in the coastal band of hydromorphic sandy soils, generally sand supported (Fig. 1). Its thickness is restricted to 0.5 m. Its lower part consists of white sand layers including organic matter debris. Above, we find a 10-centimetre-thick peaty deposit, which was dated at 7033 cal yr BP (Table 1), then some mud lamina covered by a layer of ochre sand.

KVS 6. The outcrop shows a 3.5-m-thick succession of sandy beds interlayered with organic microlayers. The first metre (unit 1) is characterised by its brown colour connected to the abundance of organic matter. The deeper layer is a brown laminated sandy silt, rich in ilmenite grains, the preserved plant debris of which were dated at $387 \mathrm{cal}$. yr BP. The 
following deposit is a brown and sandy bed $35 \mathrm{~cm}$ thick, covered by several centimetres of brown organic clay. One metre upward, the accumulation contains poorly compacted ochre or red clayey clasts, fragments of lateritic crust and some siliceous sandstones (unit 2), vestiges inherited from the Plio-Pleistocene cliffs that are less than one kilometre distant. The sand consists of ochre and pink quartz grains, mostly blunt and frosty; it is poorly sorted and some grains are aggregated by iron oxides. Ilmenite grains are abundant in fine fractions. After a pause in sediment deposition marked by a more organic horizon, mixed ochre or grey sands settled, ending at $+2.6 \mathrm{~m}$ with the deposition of a brown silty bed dated at $223 \mathrm{cal} \mathrm{yr}$ BP. Finally, the last accumulation (unit 3) consists of poorly compacted grey-beige to ochreyellow sands with lamina underlined by pigmentation contrasts.

KVS 1. Some $500 \mathrm{~m}$ from KVS 6, the sedimentary succession of KVS 1 shows a slightly similar sedimentary succession. The section begins at around one metre in altitude and shows an accumulation of grey or white sands with varied texture (unit 1). It is interrupted at around 1.50 and $2.20 \mathrm{~m}$ by centimetre-thick layers of organic mud. This bedding can be underlined by recurrent ilmenite microlayers. Above $2.5 \mathrm{~m}$, the sand becomes ochre and includes pinkish or red clayey clasts that are very poorly hardened (unit 2). Despite some alternations of clearer beds, this sandy accumulation remains dominant until $4.2 \mathrm{~m}$. Several small U-shaped troughs and ripple marks were observed. Upward, a medium-to-coarse, white or grey sand becomes dominant up to the top (unit 3), which is interrupted at $4.70 \mathrm{~m}$ by a more muddy and organic accumulation with frequent bioturbation. Pellets linked to fauna activity are juxtaposed but not intermingled in the mineral matrix of A1 horizons. At the top, the current humiferous soil is well preserved.

KVS 4. The outcrop is approximately $1 \mathrm{~km}$ from the radiocarbon dated KVS 6 . It consists of a succession of fine and coarse sandy layers deposited between 0.6 and $5.5 \mathrm{~m}$. The first unit consists of brown or white layers. Upward, white medium sand is overlain by a peaty deposit with roots and organic and fine grained laminae. At $1.30 \mathrm{~m}$, a 30-cm-thick layer of white sand with crossed stratification is covered by a succession of fine or coarse lamina of grey or white colour, the darker ones being ilmenite-rich. From $2.50 \mathrm{~m}$, ochre or reddish colours increase 
above 3 m, including a remarkable red sandy mud layer (unit 2). Near $4 \mathrm{~m}$, we still observe reddish microlayers in a bed of beige sands affected by some current ripples. Up to $4 \mathrm{~m}$ (unit 3), sand beds are white or greyish, especially at $4.90 \mathrm{~m}$ where a grey horizon is noticed. The accumulation ends with the current humic horizon, here well preserved.

The organic beds of the lower part show slightly high $\mathrm{C}$ org contents: $17 \%$ at $1.32 \mathrm{~m}$ and $5 \%$ at $2.7 \mathrm{~m}$. In spite of the low number of acceptable measures, we notice, as in KSV 2, the upward decrease of the $\mathrm{C} / \mathrm{N}$ ratio from 28.8 to 8.9 .

KVS 2. It is the southernmost section of the sector of KIvesso, some $500 \mathrm{~m}$ south of KVS 4. Globally, it is a $4.50 \mathrm{~m}$ deposition with decimetre-thick fine-to-coarse sands interlayered with thin muddy and organic microlayers. The first deposit is coarse white sand covered by finegrained lamination including remains of bark, roots or stalks, which may represent the top of unit 1, here probably buried. Then, several red or ochre sandy layers follow between 2.40 and $0.30 \mathrm{~m}$ (unit 2). Around $1.40 \mathrm{~m}$, the sand supports semi-compacted red clasts of the Série des Cirques. This accumulation is interrupted by several layers of locally hydromorphic red or brown mud. Sometimes lenses of white sand are packed within the red ochre sand. Above $2.40 \mathrm{~m}$ and up to the summit (unit 3), the sandy beds occur again in white or grey, with the exception of a red fine sand layer appearing at $4.10 \mathrm{~m}$. Near $4 \mathrm{~m}$, an immature soil crossed by some roots is observed. The current humiferous horizon was preserved at the top of the section.

The lowermost black deposit $(0.25 \mathrm{~m})$ reaches $8 \% \mathrm{C}$ org, then decreases to $3 \%$ at $1.15 \mathrm{~m}$ and to $0.6 \%$ at $3.1 \mathrm{~m}$. The $\mathrm{C} / \mathrm{N}$ ratio is very high (22.6) at the bottom of the section, but decreases markedly upward from 16.8 to 8.8 .

\subsection{X-Ray diffractometry and scanning electron microscopy}

Because of the scarcity or absence of clay minerals material, two nearby sections, KSV 2 and KSV 4, were selected as the richest in mud layers. As the lower part of KSV 4 and the upper part of KSV 2 present the higher concentrations in fine matter, the XRD-diffraction results are artificially presented on the same vertical (Fig. 4). 
Kaolinite is the most widely represented ( $>90 \%)$ clayey mineral. Halloysite is rarely observed and did not affect our comment because this mineral is a more or less hydrated kaolinite belonging to the same $1 / 1$ silicate layer group. Small amounts of degraded illite or mixedlayered illite-smectite (1 to $6 \%$ ) are sometimes linked to smectite traces and more rarely to feldspars (not displayed). Goethite crystallisations are observed mainly in the red levels. The 2/1 silicate layer contents are always low, but appear especially poor in grey sands, i.e. towards the top of KSV 2.

The scanning electron micrographs of the nanostructures allow us to recognise, in most of the red beds of Klvesso, the microneedles of goethite hiding neoformed kaolinites (Fig. 5a) or still forming cutans around quartz grains. Piles of sub-hexagonal tablets of kaolinite participate in the cementation of the microaggregates (microsandstones) and are even connected by a new generation of kaolinite or by goethite cauliflowers (Fig. 5b). Certain grains of quartz underwent an important dissolution that is obviously controlled by the orthorhombic system of the mineral (Fig. 5c). The dissolution progressed according to several steps and cavities are partially infilled by aggregates of goethite and kaolinite. In deficiency of alumina, the released silica recrystallises in the form of small neoformed glomerules on the quartz surface (Fig. $5 d$ ).

\section{Environmental interpretation}

\subsection{Loango sector comments (Fig. 6)}

The South Loango site provides the most complete sedimentary succession and is also the best dated. According to Jamet and Rieffel (1975), the lowermost grey-greenish sandy mud corresponds to a hydromorphic soil (gley). This gley is a supported sandy deposit. Near the site, the map of surface soils indicates a filled swampy depression of more than one kilometre parallel to the shoreline. South Loango is located more or less on the side of this depression (facies 2 on the map). Then the overlying sandy deposit underwent an intense podzolisation: a leached "cleared" horizon recovers an important accumulation of organic matter associated with iron ending in concretions (iron pan). The leached white sand derives 
probably from the Série des Cirques. Its homogeneity and rather good sorting would suggest an aeolian final deposition.

The first deposits of North Loango 1 correspond to the upper part of the podzol soil of the previous South Loango section. The following three metres include a succession of thin finegrained laminae deposited in confined swamps sheltered from the main channels. This episode ends at about 2500 cal BP. The last step of the deposition consists of ungraded medium sand, probably of colluvial origin.

Due to a higher altitude of the bedrock, the North Loango 2 section shows nearly preserved podzol horizonation (A horizon and iron pan), but the laminated accumulation is very condensed. It quickly makes way for the alluvial filling, which is restricted to two main flood sequences that have submerged the hillsides of the site. The end of the deposition process, nearly one metre-thick, suggests a colluvial deposition.

The $\mathrm{C}$ org content of the flood sequences of the upper part of the section do not exceed $0.45 \%$, their low $\mathrm{C} / \mathrm{N}$ ratio $(7.4-10)$ underlines an immature organic matter, thus contrasting with those of deeper and older swampy soils.

\subsection{KIvesso sector comments (Fig. 6)}

The very short KVS 7 section belongs to a coastal sector severely eroded by the oceanic swell; thus, it allows us to observe and to date only the ultimate steps of the Holocene swampy forest. The white sand is crossed by some roots representing the upper part of the podzol A horizon and the peat layer results from the superficial forest accumulation. The 7093 cal BP age is compatible with those of similar deposits in the Loango area (South Loango section) and the nearby coastal sectors (Schwartz et al., 1985; Dechamps et al., 1988; Elenga et al., 1992). Some centimetre-thick muds represent the ultimate remains of the first swampy deposition that was largely described in North Loango 1 and 2.

The KVS 6 section, during the restricted history of the last four centuries, testifies to an active accumulation resulting from the closeness of the Plio-Pleistocene cliffs of Diosso Gorges.

The equivalent deposits in KV7 were probably destroyed as a direct consequence of oceanic erosion. The KVS6 accumulation is not strictly colluvial because it associates and mixes 
materials of various origins, including ferrallitic ochre sand and leached clear sand, and shows various structures of sporadic river transportation. It presents coarse sequential accumulation ending with pauses of sediment deposition leading to the first steps of young swampy soil settlements. The sketches of the sequences do not present the upward grading observed in the alluvial accumulations of North Loango 1 and 2. Nevertheless, recurrent swampy episodes are attested by organic microlayers and isolated laminations at the bottom of the section.

On the basis of the chronology provided by KVS 6, KVS 1 also represents a recent and active accumulation directly fed from cliffs close to the Diosso Gorges. In the lower part of the section, fine and organic sediments and some muddy laminations indicate the temporary extent of swampy surfaces. Then, the deposits show alternations or mixtures of the erosion products of the fossil ferrallitic remains and podzolised material of the littoral plain. The first ones, with their ochre sands and pink or red clasts, constitute a sedimentary unit quite similar to that observed between 1.20 and $2.50 \mathrm{~m}$ in KVS 6 . Although these deposits appear mostly colluvial, they present, as in KV 6, some discrete characters of river transportation. Compared with the nearby sections, this 4.5-m-thick KSV 4 accumulation appears to have remained sheltered from oceanic erosion. In spite of some lithological differences, the sedimentary history of the last four centuries shows a three-units succession rather similar to those of KVS 6 and KVS 7. Included in a mainly sandy and colluvial background, some clayey layers or microlayers express short episodes of swampy flood. Near $1 \mathrm{~m}$, a succession of peats with roots and organic clay could correspond to mud lamination dated at 387 cal yr BP in KVS 6. However, we cannot observe, as in sections further north, the coarse clasts stemming directly from the Série des Cirques erosion. The organic beds of the lower part show slightly high C org contents that decrease upward, as in KSV 2. The upward decrease of the $\mathrm{C} / \mathrm{N}$ ratio is observed from 28.8 to 8.9 , suggesting a renewal of the sources of the organic matter and faster accumulation.

Despite a marked recurrence of swamp flood episodes (centimetre-thick fine-grained layers) or transient settlements of flooded forest soils, KSV 2 again allows us to observe a 
succession of varied sandy beds with higher energy intervals, where reworked compacted clasts of the Série des Cirques were deposited as in KSV 6 and KSV 1. The energy of this transport is attested by current ripples and reworked sand packages, the deposit here resembling a debris-flow. KVS 2 is the outcrop where the sequential aspect of the accumulation is the most marked. The swampy environment is rather long lasting, as indicated by recurrent thin forest soils with mature $\mathrm{OM}$, but upward, the $\mathrm{C}$ org content and $\mathrm{C} / \mathrm{N}$ ratio decrease (Table 2 ). In spite of probable sedimentary pauses, on the basis of the textural succession and the degree of oxidation/leaching, a simplified unit succession can be proposed as a correlation base (Fig. 6):

(unit 1) from the basis until around $2.50 \mathrm{~m}$, white or grey sediments indicate leaching in a flooded environment,

(unit 2) from around $2.50 \mathrm{~m}$ until around $4 \mathrm{~m}$, ochre deposits with some clayey microbeds of reddish colour indicate a colluvial process and a swampy environment, sands and clay from the ferrallitic horizons of the Série des Cirques are directly transported to the costal site, (unit 3) from around $4 \mathrm{~m}$ to the top, the direct erosion of the Série des Cirques becomes more discrete and the main part of the material again corresponds to reworked particles from leached soils.

\subsection{Mineralogy comments}

In a global approach, the greater part of this Holocene sedimentary accumulation originates from the Série des Cirques accumulation, cliffs of which dominate a few hundred metres away, in particular around Kivesso. KVS4 clayey assemblages are essentially made of badlyto well-crystallized kaolinite with low amounts of illite. These minerals were strongly degraded due to the recurrent reworking accumulation. Even if the clay minerals accumulation of Série des Cirques is still poorly documented, our observations meet those of some previous works (Massengo, 1970; Jamet and Rieffel, 1976). Even above the magnesian bedrocks of the Mayombe basement, kaolinite is largely dominant associated with open illite and goethite, montmorillonite being restricted to the immediate proximity of the bedrock (Jamet and Rieffel, 1976). 
Halloysite is slightly more abundant in the lower part of KSV4 and, like the goethite and the traces of smectites, indicates the presence or the closeness of the indurated red clasts. This clay mineral acts here as a proximal mineral, as it characterises the presence of materials shortly reworked from the Série des Cirques. It was recognised in several soils of the western Mayombe as alteration products of the feldspars and biotites of the metamorphic basement (Jamet and Rieffel, 1976) and accumulated in the sandy bodies of the Série des Cirques (Jamet and Rieffel, 1976).

It is suggested that some noticeable contents of the $2 / 1$ silicate layers at the bottom of KSV 4 could express some direct reworking from the underlying Cretaceous bedrock (Giresse and Tchikaya, 1975). The upward disappearance of halloysite and goethite (KVS2 upper part) can indicate more distal sources or at least more alluvial transport.

Some examples of neoformed silica were observed on quartz grains of various beds of Loango and Kivesso, but are more frequent at Kivesso, where they are associated with kaolinite and goethite neoformations and characterise the clastic supply inherited from the Série des Cirques.

\section{Organic matter analyses, results}

The organic deposits are intermittent and restricted to some thin layers. In such conditions, it was not possible to propose continuous analyses at the vertical log scale as exemplified by various lake or deep swamp studies of the same region (Giresse et al., 2005; Sebag et al., 2013). Accordingly, the positions of the analysed organic layers will be arrowed on logs and the analyses will be commented on the basis of tables or synthetic diagrams.

\subsection{Rock-Eval pyrolysis}

Eight organic levels, 2 from Loango and 6 from Kivesso, were selected according to their relatively high $\mathrm{OM}$ concentration and to the available ${ }^{14} \mathrm{C}$ ages. In such occurrences, some 
ages were only estimated by correlation with nearby levels or sections (Fig. 2 and 3).

The Total Organic Carbon (TOC) contents appear highly variable (ranging from 1 to $23 \%$ ) and independent from the site and age of the deposit. Substantially peaty deposits with abundant bark debris are found near Loango in accumulations dating more than 7000 years, with concentrations reaching $23.3 \%$ TOC.

In a former approach, the OM provenance appeared mostly linked (1) to submerged and/or emerged trees colonising the whole waterbody and (2) to reworking from the catchment area. Light microscopy observations did not show the presence of diatoms or microalgae composed of Botryococcus, suggesting a low water table and strongly limited planktonic and benthic algae growth.

One objective was to compare these Holocene Loango organic accumulations with welldocumented ones located slightly near the studied site. Thus, Lake Kamalété (Gabon), situated approximately $500 \mathrm{~km}$ from Loango-Kivesso, allows us to compare a lacustrine environment (Sebag et al., 2013) with our swampy forest sites. The soils feeding the accumulation were analysed with nearly the same methods as ours in the plain very close to Pointe-Noire (Disnar et al., 2003), thus they establish within a $50 \mathrm{~km}$ radius a useful reference for the provenance of Loango-Kivesso deposits.

Fig. 7 indicates a correlation between S2 (i.e. hydrocarbon compounds produced by thermal cracking of $\mathrm{OM}$ ) and $\mathrm{S}_{3} \mathrm{CO}_{2}$ (i.e. $\mathrm{S}_{3} \mathrm{CO}_{2}$ produced by thermal cracking of $\mathrm{OM}$ and siderite). The low $\mathrm{S}_{3} \mathrm{CO}_{2}$ relative to $\mathrm{S} 2$ may underline the strong dominance of OM-derived compared with carbonate-derived signals. Indeed, aggregates of small siderite prisms are very scarcely included in only some beds. The same correlation was previously evidenced for gabonese Lake Kamalete deposits with, however, higher $\mathrm{S}_{3} \mathrm{CO}_{2}$ values, as presented in the same Fig. 7. Consequently, major changes in the $\mathrm{IO}$ are mainly related to sedimentary organic matter and not to the mineralogical components (i.e. very low iron carbonate content). TOC contents allow us to distinguish (1) organic or peaty facies (TOC>16.5\%), (2) OM-rich $(9.4 \%<\mathrm{TOC}<16.5 \%)$, and (3) OM-poor (TOC<5\%) (Fig. 8a). This OM-base typology corresponds to organic facies: e.g. respectively, peats with high OM contents, black 
laminations with medium OM concentration and accumulation soil horizons that usually present low OM concentrations.

The temperature peak (TpS2) is characteristic of humic matter maturation, high values are typical of immature humic substances. Previous measurements were obtained on surface horizons A1 on ferrallitic arenosols from the nearby Pointe-Noire savanna. TpS2 is between 453 and $471{ }^{\circ} \mathrm{C}$, while Loango-Kivesso values ranging from 418 to $471{ }^{\circ} \mathrm{C}$ are nearly in the same variance. However, the very low (mature) values of 320 to $390^{\circ} \mathrm{C}$ analysed in the upper horizons of the Pointe-Noire soils were not found in Loango-Kivesso (Fig. 8a). High Hydrogen Index $(\mathrm{HI})$ values are significant of the terrestrial vegetals rich in polysaccharides and lignin, consequently $\mathrm{HI}$ appears rather connected to humic matter. In the unweathered mineral soils, $\mathrm{HI}$ shows a decrease during the humification process of $\mathrm{OM}$ and a relatively high $\mathrm{HI}$ characterises poorly transformed vegetal matter or anoxic soils litters in the absence of biological activity (Disnar et al., 2003). Similarly, in Loango-Kivesso, HI values are relatively high throughout the series, i.e. between 224 and $321 \mathrm{mg} \mathrm{HC}^{-1} \mathrm{~T}^{-1} \mathrm{TOC}$ (with only one exception at soil 103), as expected for a material believed to have arisen primarily from terrestrial plants (Espitalié et al., 1985). As previously noted, Kivesso sediments show laminated structures and sand or silty grain size proceeding from alluvial transport. The lowest $\mathrm{HI}$ corresponds to the muddy lamination at the base of KSV 6; similar $\mathrm{HI}$ values were obtained in various deep horizons of the savanna soils of Pointe-Noire, in particular in the B21h and B22h indurated spodic horizons.

Generally, high oxygen index (OI) values (>300 $\mathrm{mg} \mathrm{O}_{2} / \mathrm{g} \mathrm{C}$ org) indicate a strongly altered OM (Copard et al., 2006). By comparison, Loango-Kivesso Ol values are low (<200 and mainly $<70 \mathrm{mg} \mathrm{O}_{2} / \mathrm{g}^{-1}$ ), indicating a generally well-preserved OM (Fig. 8b). The highest values correspond to sand-rich deposits of the Kivesso area; note especially the $177 \mathrm{mg}$ $\mathrm{O}_{2} / \mathrm{C}$ org measured in the peaty silt of KSV7 2. Most of the detrital sequence of the Kivesso area originates from the active erosion of the cliffs of the Série des Cirques. These low OI values are associated to slightly low $\mathrm{HI}$ values, indicating the detrital terrestrial OM origin without aquatic planktonic matter. These values are lower than those of the nearby sandy 
soil A horizons of the Pointe-Noire savannas, which are included between 80 and 273 . The

OI values of this Loango-Kivesso study are mainly lower than 100 , indicating the almost ubiquist character of the swampy deposition.

Two Kivesso-Loango sample groups can be distinguished through $\mathrm{HI}$ and $\mathrm{OI}$ values (Fig. 8b). The first group (two samples), consisting of peaty sediment and laminated dark muds, corresponds to low OI values nearly included in the field of Kamalété deposits. The second group (four samples) presents a distinct signature characterised both by very low OI values ( $<100 \mathrm{mg} \mathrm{O}_{2} / \mathrm{g} \mathrm{C}$ org) and slightly high $\mathrm{HI}$ values ( $\left.>280 \mathrm{mg} \mathrm{HC} / \mathrm{g} \mathrm{C} \mathrm{org}\right)$. The measures realised by Disnar et al. (2003) on various A1 and A2 surface horizons of ferrallitic soils of the nearby Pointe-Noire lowland were added on the same graph. They are in the field of the deposits of Lake Kamalété, but outside the essentially lacustrine deposition of the organic layers of Loango-Kivesso.

\subsection{Organic carbon isotopic analyses}

The isotopic composition of the carbon of higher plants distributes according to two functional modes of their cycle of photosynthesis (cycle in C3, cycle in C4) (Bender, 1971; Smith and Epstein, 1971). During photosynthesis, ${ }^{13} \mathrm{C}$ is a little heavier and slightly less absorbed than ${ }^{12} \mathrm{C}$. These small differences can be observed in relation to the type of photosynthesis used. Plants that use the C4 cycle from open tropical landscapes (here mostly Poaceae and Cyperaceae) absorb more ${ }^{13} \mathrm{C}$ than $\mathrm{C} 3$ plants (all forest tree species and practically all other plants). This differential isotopic marking is transmitted in organic matters of the soil. Analysed organic sediments were chosen in different sections of Loango and Kivesso. The measures of $\delta{ }^{13} \mathrm{C}$ are presented in a synthetic graph according to the age, either measured or sometimes extrapolated by correlation (Fig. 9). The deposits younger than 500 years belong to the Kivesso site, while those between 7000 and 2500 BP stem, with two exceptions, from the Loango site.

The oldest deposits, close to $7000 \mathrm{yr}$ cal BP, show $\delta{ }^{13} \mathrm{C}$ values between -28 and $-26 \%$. Then, from 6700 to $5000 \mathrm{yr}$ cal BP, values shift between -24 and $-22 \%$ and then by $2500 \mathrm{yr}$ 
cal BP, according to distinct sites, reach $-21 \%$ and $-16 \%$. In the much more recent deposits of Kivesso, the majority of the values between -28 and $-26 \%$ correspond to levels with ages between 500 and $350 \mathrm{yr}$ cal BP. Then, slightly less negative values make the transition after $350 \mathrm{yr}$ cal BP. Finally, the three most recent deposits (younger than $200 \mathrm{yr}$ cal BP) indicate $\delta$ ${ }^{13} \mathrm{C}$ between -17 and $-15 \%$, which are values rather close to those obtained around $2500 \mathrm{yr}$ BP.

\section{Interpretation of the organic matter study}

\subsection{Comments on the Rock-Eval pyrolysis}

In such peatlands with terrestrial higher plants, OM is mostly composed of products derived from lignin, hemi-celluloses and cellulose. Its preservation is favoured by an anoxic environment and rapid burial (Clymo, 1983).

The layers of abundant organic matter accumulation, with stalks and roots frequently in the live position, are observed in the lower part of nearly each section. These oldest deposits are the richest in $\mathrm{C}$ org with the lowest $\mathrm{C} / \mathrm{N}$ ratio values. Ratio $\mathrm{C} / \mathrm{N}<10$ are compatible with those of most of the A surface horizons of the young ferrallitic arenosol of the Pointe-Noire lowland area. Higher ratios were found only in the B horizons of humic podzols (Disnar et al., 2003).

In a previous study of Lake Kamalété in southern Gabon, Sebag et al. (2013) discriminated two sedimentary facies dominated (1) by detrital terrigenous inputs with 'iron bearing' signatures and high OI values, and (2) including a higher primary production (chlorophyll signature, low $\mathrm{Ol}$ and high $\mathrm{HI}$ ). The low $\mathrm{Ol}$ and high $\mathrm{HI}$ values of Loango-Kivesso are included clearly in the second facies; three deposits can be integrated in the sediments of Kamalété field, but five others suggest a better-preserved vegetal contribution, which is unknown in Kamalété. However, even though higher primary production is not clearly attested in these deposits, submerged and/or emergent vascular plants colonise swamp margins or the whole waterbody. In peatlands, OM preservation is favoured by an anoxic environment and rapid burial (Clymo, 1983). By way of comparison, the peats of the Jura 
region showed rather high $\mathrm{HI}$ concentrations ranging from 370 to $450 \mathrm{mg} \mathrm{HC} . \mathrm{g}^{-1} \mathrm{TOC}$. Loango-Kivesso $\mathrm{HI}$ values are rather high for continental peats and could at least partly be explained by the admixture of aliphatic algal components, even if the presence of algae was not shown by microscopic observations. High $\mathrm{HI}$ values would indicate rather long-lasting conservation in a swampy environment and the lowest values that might indicate alternating episodes of emersion and immersion. Such differences suggest an opposition between a more or less autochthonous primary vegetal production and another that is more detrital or previously subjected to a prolonged phase of transport. During transport to the marsh, as well as during deposition and early diagenesis, many processes may alter the original characters of organic sources. Analyses on another peaty Jura sequence showed that the trend of OI corresponds in fact to a loss or to OM rich in oxygen during microbial degradation (Delarue et al., 2010); such a process would also be appropriate to explain the low values obtained in Loango-Kivesso. Thus, in the Jura peats, $\mathrm{Ol}$ is strongly connected to polysaccharides, varying from 263 to $169 \mathrm{O}_{2} \mathrm{~g}^{-1} \mathrm{TOC} \mathrm{g}^{-1}$ (Disnar et al., 2003; Sebag et al., 2006).

Two main accumulation periods can thus be distinguished in the core: (1) a peaty phase between ca. 7000 yr BP and ca. 3000 yr BP (medium water table but probably limited microalgal growth, (2) a waterlogged marsh phase, from ca. $3000 \mathrm{yr}$ BP to ca. $500 \mathrm{yr}$ BP, in which small alluvial events were recurrent, especially in the Kivesso area. Lastly, alluvial aggradation intensified as a result of precipitation increase. Three 'more lacustrine' points correspond to sections of the Kivesso coast (KVS 2, KVS 6, and KVS 7 sections) where we observe the active erosion and colluviation of the cliff slopes of the Série des Cirques: this sedimentary process is similar to that acting along the steep slopes of the narrow Kamalété watershed.

\subsection{Comments on the $\delta^{13} \mathrm{C}$ of the organic matter}

The $\delta^{13} \mathrm{C}$ of the organic matter of the current soils of Congolese rain forests ranges between -26 and $-28 \%$. In nearby savannas, it ranges between -12 and $-18 \%$ or -12 and $-16 \%$, depending on the content of woody plants (Schwartz, 1991; PIGB-PMRC-France, 1997). In 
the Pointe-Noire savanna, 12.2 and 13.1 ratios were respectively obtained for Loudetia and Hyparrhenia, the two most frequent genera (Schwartz et al., 1990). Intermediate values are characteristic of climatic and vegetal cover changes, especially when forest encroaches on savanna. So values for $\delta^{13} \mathrm{C}$ can be used as climatic change proxies. Our previous analyses showed that the particles of planktonic origin probably played only a minor role in the organic accumulation: during the peaty phase, the prevalent autochthonous origin is associated with the vascular plants, while during the water-logged swamp phase, the episodes of floods are responsible for brief and recurrent allochthonous accumulations. We are thus justified to consider in this regional context the variations of the isotopic ratio as widely dependent on the vegetal cover change.

The $\delta{ }^{13} \mathrm{C}$ of older peats dated at ca. 7000 cal BP range between -26 to $-28 \%$, typical values for a C3 origin. It was a dense hydromorphic forest including various species of Monopetalanthus and Saccoglottis and medium-size trees and shrubs (Dechamps et al., 1988; Elenga et al., 1996; Bertaux et al., 2000). Other pieces of wood from this forest were dated at ca. 6800 and ca. $4710 \mathrm{yr}$ BP, i.e. an interval corresponding to a still wet Holocene. Then, the $\delta{ }^{13} \mathrm{C}$ profile testifies to the replacement of an ancient forest by a new savanna. This trend towards slightly drier conditions is indicated at ca. $2500 \mathrm{yr}$ cal BP by $-21 \%$ and $16 \%$ values, suggesting a forest-savanna mosaic. This trend was also recognised in various sites of central Africa, i.e. forest extent from 7000 , then its retreat after 4000 or $3000 \mathrm{yr}$ BP according to the edaphic conditions. Some $10 \mathrm{~km}$ south of Loango, near $1600 \mathrm{yr} \mathrm{BP}$, an earlier forest recurrence is characterised by the presence of a Syzygium secondary forest (Elenga et al., 1992).

Between 500 and $350 \mathrm{yr} \mathrm{BP}$, the various -26 to $-28 \%$ 。 3 values registered in the Kivesso area marked the increase in precipitation, at least on the scale of this coastal area and thus a strengthening of the erosion of the Diosso amphitheatre. Previous studies in the same area indicated three ${ }^{14} \mathrm{C}$ ages ranging between 600 and $480 \mathrm{yr}$ BP (Schwartz et al., 1992). They underline the transition from a fine-grain deposition in a swampy environment to a coarsegrain alluvial deposition. Similarly, the last 500-year records of Lake Kitina indicate the 
progressive return of forest, lianas and Cyperacea taxa to the detriment of heliophilous and herbaceous taxa (Elenga et al., 1996). A similar episode was also recorded in the Niari plateau at about $650 \mathrm{yr}$ BP (Vincens et al., 1994) and towards 600-550 BP on the nearby Atlantic coast (Schwartz et al., 1990; Elenga et al., 1992).

The relative novelty of this reconstruction concerns the revealing of an ultimate drier trend during the last two centuries that has been attested by a $\delta{ }^{13} \mathrm{C}$ ratio indicating a clear decrease of the forest extent. It is suggested that this last episode was linked to variable Kivesso edaphic conditions. Thus, at the scale of the hills and plateau of the coastal hinterland, the return of the forest after 3000 BP has never been demonstrated (Schwartz et al., 1992)

\section{Synthesis of the Holocene environmental trend of Loango Bay}

\subsection{Fresh water conditions of Loango-Kivesso wetlands}

At the arrival of the last transgression, the Kouilou estuary (around $15 \mathrm{~km}$ north) showed fine organic deposits, even mangrove muds dated at 9896 yr BP corresponding to the proximity of the banks of this estuarine valley. Similarly, on the basement of Pointe-Noire Bay, around 7-9000 yr BP and between 25 and 29 m deep, the mangrove deposition settled sporadically on the palaeoestuary, which worked upon the arrival of the transgression (Giresse, 1981; Delibrias et al., 1973; Giresse and Kouyoumontzakis, 1974). Another example of mangrove deposit is provided by the narrow valley of the Songololo estuary, which was occupied from approximately 7000 to $4000 \mathrm{yr}$ BP. At about $3000 \mathrm{yr}$ BP, the mangrove swamp disappeared and the environment evolved toward a swampy Cyperaceae and fern meadow (Elenga et al., 2001).

However, this Loango-Kivesso area shows no Holocene marine proxy, nor even any marine influence above the zero. Such observation joins the previous conclusions on the scale of Congo as well as the broader conclusions covering the whole Gulf of Guinea (Delibrias et al., 1973; Girese et al., 1984). Consequently, in the Loango-Kivesso, mangrove remains are generally absent in Late Holocene deposits that were developed in confined fresh water 
swamps after 6-7000 cal yr BP. No plant vestiges, animals (Ostrea or Mactra bioclasts), nor any commonly associated mineralisation like gypsum or jarosite were discovered.

\subsection{Late Holocene environmental trend of Loango-Kivesso}

From 7-6000 yr BP, the accumulation of important beach barriers by the oceanic drift allowed the definition of a narrow swamp depression at least several tens of kilometres long, although most probably interrupted. We recognise obvious evidence of the Holocene wet forest setting from the north of Pointe-Noire to the mouth of the Kouilou. Some pieces of wood and peat were previously dated between 6500 and $3000 \mathrm{yr}$ BP in the north of PointeNoire (Dechamps et al., 1988; Schwartz et al., 1990; Elenga et al., 1992). It was a dense ombrophile and hydromorphic forest allowing accumulations of peat and organic muds. Peat precursors are mainly terrestrial higher plants. Big trees with various species of Monopetalanthus and Saccoglottis were found. This forest was affected successively by periods of dehydration and flooding involving the oscillation of the water table without the influence of brackish waters.

This swampy forest was especially favourable to the podzol process, while areas of stable water table can correspond to local accumulations of the peat bog type, only locally observed (Schwartz, 1985). Five pieces of Monopetalanthus wood were dated between 5800 and 3100 yr BP, i.e. an interval corresponding to a still wet Holocene and which precedes the trend towards slightly drier conditions. Three other datings of organic matter of the podzol accumulation horizons indicate ages between 6540 and $3700 \mathrm{yr} \mathrm{BP}$, confirming the contemporaneous nature of the whole vegetal cover. Our four calendar ages from LoangoKivesso sections from $6255 \mathrm{yr}$ BP to $4155 \mathrm{yr}$ BP (i.e. 7205 to $4710 \mathrm{cal}$ yr BP) are thus located in nearly the same chronological interval.

From a general palaeoecological point of view, it is clear that forest in a broad sense did not only cover the coastal plain during the lower-Holocene, but also all the hill and plateau area between the coastline and the Mayombe mountain zone (Schwartz et al., 1992).

\subsection{Emersive trend of $3000-2000$ yr BP}


According to the end of the depression filling, the passage from a vast forest swamp with a waterbody several metres deep to a wet zone with some emersions is indicated by an extensive hydromorphic soil development. Hydromorphic soils emerged intermittently and extended (especially near Kivesso) according to both the end of the filling process and to a regional scale drier climatic trend. Here, this interval is dated by the $2516 \mathrm{cal}$ yr BP age of brown lamination in North Loango. This arid trend was responsible for the extension of open types of vegetation rich in grasses in many parts of Congo. To the north of Pointe-Noire Bay, on the banks of the Songololo mouth, some slabs of blue-grey or blackish clayey deposits appear at $0.5 \mathrm{~m}$ above the present high water, their organic matter was dated at $2920 \mathrm{yr}$ BP (Elenga et al., 2001). However, in the Niari region, this climatic interval has been shown as a complete drying up of Lake Sinnda at 4000 BP whereas in some sites throughout Congo (Schwartz et al., 1990 and 1992; Elenga et al., 1992; Vincens et al., 2000), it was recorded ca. 3000 BP. Then, in spite of a short recurrence of a Syzigium secondary forest, near 1600 yr BP, at Coraf refinery (near Pointe-Noire), the decrease or disappearance of the forest environment was observed: the pollen assemblage reached more than $80 \%$ of Gramineae associated with swampy taxa (Elenga, 1992).

\subsection{Late increased soil erosion}

At Kivesso, several proxies suggest a net renewal of the erosion on the restricted scale of the last centuries. In this way, the most significant information concerned the passage from a fine-grain deposition in a swampy environment to slightly coarse alluvial sequences.

During the last filling of the Kouilou estuary, successive avulsions of the main and secondary channels of the river and general downstream progradation of the alluvial deposits reflect a shift to a more erosive climatic interval with globally more contrasted and abrupt floods (Giresse and Moguedet, 1982). At Lake Kitina (western Mayombe): a phase of delayed forest reconquest is associated with a clear precipitation increase after $500 \mathrm{yr}$ BP inducing the disappearance of included savanna (Elenga et al., 1996). A late Holocene episode was also recorded in the Niari region with the extent of large swampy areas and running fresh water around Lake Sinnda from 650 yr BP (Vincens et al., 1994). Over greater distances, as on 
Plateaux Bateke, at Ngamakala, swampy forests reappeared gradually from $900 \mathrm{yr}$ BP. Lastly, during the last two centuries, Kivesso $\delta{ }^{13} \mathrm{C}$ ratio records indicate an ultimate decrease of the forest extent. It is possible that this last episode was linked to local edaphic conditions, because a few kilometres away, on the Pointe-Noire plateau, the return of the forest after 3000 BP has never been demonstrated (Schwartz et al., 1992).

\section{Conclusions}

The Mid-Holocene to Late Holocene swampy forest environment of Loango-Kivesso was still little known from the point of view of the geochemistry of its organic matter. Despite being very close to the oceanic coast, it remained isolated from any brackish influence. It was a forest swamp covered by 1-2 $\mathrm{m}$ of water that remained long-lasting during approximately 45000 years and which allowed the accumulation of fresh water peaty deposits of a type little known in tropical Africa. The black layers with organic matter concentration and stalks and roots, sometimes in a spectacular live position, are frequently observed at the bottom of each section, especially around Loango.

On the basis of the recent study of organic matter of nearby Lake Kamalété sediment (Sebag et al., 2013), it is possible to characterise OM geochemical signatures related to main environmental processes suggesting a distinction between lacustrine and palustrine dynamics. According to the low $\mathrm{Ol}$ and high $\mathrm{HI}$ values of Loango-Kivesso, an opposition is suggested between a more or less autochthonous primary vegetal production, i.e. terrestrialand aquatic-borne organic matter. The sections involved expressed the intense erosional processes on the slopes of the cliff of Diosso. Such depositions may result from a seasonal high contrast, favouring runoff and mass wasting on the slopes covered with sparse vegetation. Thus, higher OI values ( $>300 \mathrm{mg} \mathrm{O}_{2} / \mathrm{g} \mathrm{C}$ org) similar to those from deep soil horizons (Disnar et al., 2003) or indicating a strongly altered OM (Copard et al., 2006) have never been recorded in this area.

It is advisable to insist on the fact that these forest and swamp occurrences during the Late Holocene were not isolated features, their lateral extents are evidenced on a coastline of 
more than $15 \mathrm{~km}$ in length and it is likely that new discoveries will be made according to the present erosion and the future backward movement of this Congolese shore. At about 6000 yr BP, the implementation of seasonal or long-lasting swamps was certainly enhanced by increasing rainfall, but these precipitations had already previously been active for several millenniums. So, it was both the approach and the arrival of the oceanic shoreline to its present level that were determining by decreasing or stopping the downward drainage of continental waters. The rapid accumulation of beach barriers linked to the powerful oceanic drift largely insured the isolation and the settlement of the swampy ponds.

Figure 9 is a proposal for the palaeoenvironmental trend of this coast on the scale of the Holocene highstand. It suggests, around 7000 yr BP, an initial building of aeolian beach barriers and a fast isolation of the forest swamps followed by the extended accumulation of the peaty layer and by podzol soil development (especially accumulation horizons). Between 3000-1000 yr BP, the decrease of the precipitation together with the filling of the ponds enhanced hydromorphic soil developments and local emersion. After $1000 \mathrm{yr} \mathrm{BP}$, and particularly after $500 \mathrm{yr} \mathrm{BP}$, a widespread trend to precipitation increase is recorded, even if the processes were slightly diachronous according to each local edaphic condition.

\section{Acknowledgment}

This work was partially funded by BRGM (French geological survey) in the framework of its geological mapping program of Congo to 1 / 100,000 under the responsibility of Yannick Callec. We would also like to thank Christophe Menniti (CEFREM, Perpignan University) for $\delta^{13} \mathrm{C}$ isotopic signatures analysis in the CEFREM (Perpignan University). Instructive comments of two anonymous reviewers substantially improved the manuscript and were greatly appreciated.

\section{References}

Bender, M. M., 1971. Variations in the ${ }^{13} \mathrm{C} /{ }^{12} \mathrm{C}$ ratios of plants in relation to the pathway of photosynthetic carbon dioxide fixation. Phytochemistry 10, 1239-1244.

Bertaux, J., Schwartz, D., Vincens, A., Sifeddine, A., Elenga, H., Mansour, M., Mariotti, A., Fournier, M., Martin, L., Wirrmann, D., Servant, M., 2000. Enregistrements de la phase sèche d'Afrique centrale vers 3000 ans BP par la spectromètrie IR dans les lacs Sinnda et Kitina (Sud Congo) M. Servant M and Servant-Vildary S (eds.), Dynamique à 
Long Terme des Écosystèmes Forestiers Intertropicaux, IRD/UNESCO/MAB/CNRS, Paris, pp. 43-49.

Bostoen, K., Clist, B., Doumenge, C., Grollemund, R., Hombert, J-M., Koni Mulawa, J., Maley, J., 2015. Middle o Late Hoocene Paleoclimatic Change and the Early Bantu Expansion in the Rain Forests of Western Central Africa. Current Anthropology 56, 3, 354-383.

Bourgoin, V., Reyre, D., Magloire, P., Krichewsky, 1963. Les canyons sous-marins du Cap Lopez. Cahiers océanographiques 15, 372-387.

Burke, K., Gunner, V., 2008. The African Erosion Surface : a continental-scale synthesis of Geomorphology, Tectonics, and Environmental Changes over the last 180 Millions years. The Geological Society of America, Memoir 201, $59 \mathrm{p}$.

Clymo, R.S., 1983 ; Peat. In: A.J.P. Gore (Editor), Ecosystems of the World. Mires: Swamp, Bog, Fen and Moor. General Studies. Elsevier, Amsterdam, pp. 159-224.

Copard, Y., Di-Giovanni, C., Martaud, T. et al. , 2006. Using Rock-Eval 6 pyrolysis for tracking fossil organic carbon in modern environments: Implications for the roles of erosion and weathering. Earth Surface Processes and Landforms 31(2), 135-153.

Cosson, J., 1955. Notice explicative sur les feuilles Pointe-Noire et Brazzaville. Carte géologique de reconnaissance au 1/500 $000^{\circ}$. Directions Mines et Géologie A.E.F. Brazzaville, $56 \mathrm{pp}$.

Dechamps, R., Guillet, B., Schwartz, D., 1988. Découverte d'une flore forestière mi-holocène (5800-3100 BP) conservée in situ sur le littoral ponténégrin (R.P. du Congo). CompteRendus Académie des Sciences 306 (II): 615-618.

Delarue, F., Laggoun-Défarge, F., Disnar, J.R., Lottier, N., Gogo, S. , 2010.Organic matter sources and decay assessment in a Sphagnum-dominated peatland (Le Forbonnet, Jura Mountains, France) : impact of moisture conditions. Biogeochemistry 106, 1, 3952.

Delibrias, G., Giresse, P., Kouyoumontzakis, G., 1973. Géochronologie des divers stades de la transgression holocène au large du Congo. Compte Rendus Académie des Sciences 276: 1389-1391.

Disnar, J.R., Guillet, B., Kéravis, D., Di-Giovanni, C., Sebag, D., 2003. Soil organic matter (SOM) characterization by Rock-Eval pyrolysis: scope and limitations. Organic Geochemistry 34, 327-343.

Elenga, H., 1992. Végétation et climat du Congo depuis 24000 ans B.P. Analyse palynologique de séquences sédimentaires du pays Bateke et du littoral. Doctoral Thesis Univ. Aix-Marseille-III, 238 pp. 
Elenga, H., Schwartz, D., Vincens, A., 1992. Changements climatiques et action anthropique sur le littoral congolais au cours de l'Holocène. Bulletin Société Géologique de France, 163, 85-90.

Elenga, H., Schwartz, D., Vincens, A., Bertaux, J., de Namur, C., Wirrmann, D., Servant, M., 1996. Diagramme pollinique du Lac Kitina (Congo) : mise en évidence de changements paléobotaniques et paléoclimatiques dans le massif forestier. Compte Rendus Acadèmie des Sciences 323 (lia), 403-410.

Elenga, H., Vincens, A., Schwartz., Fabing, D., Bertaux, J., Wirrmann, D., Martin, L., Servant, M., 2001. Le marais estuarien de la Songololo (Sud Congo) à l'Holocène moyen et récent. Bulletin Société Géologique de France 172 (3), 359-366.

Espitalié, J., Deroo, G., Marquis, F. 1985. Rock Eval pyrolysis and its application. Revue de I'Institut français du Pétrole 40(5), 563-579.

Giresse, P., 1981. Les sédimentogenèses et les morphogenèses quaternaires du plateau et de la côte du Congo en fonction du cadre structural. Bulletin de l'Institut Fondamental d'Afrique Noire, Dakar 43 (A 1-2), 43-68.

Giresse, P., Kouyoumontzakis, G., 1974. Observations sur le Quaternaire côtier et sousmarin et des régions limitrophes. Aspects eustatiques et climatiques. Association Sénégalaise Études Africaines, Bull. Liaison, Sénégal 42-43, 45-61.

Giresse, P., Tchikaya, J.B., 1975. Contribution à la carte géologique de la plate-forme sousmarine congolaise (Mission N.O. Nizery de janvier 1974). Annales Université Brazzaville 11(C), 23-34.

Giresse, P., Jansen, F., Kouyoumontzakis, G., Moguedet, G., 1981. Les fonds du plateau continental congolais et le delta sous-marin du fleuve Congo. Bilan de huit années de recherches sédimentologiques, paléontologiques et géophysiques. In : Fontana (Ed), Travaux et Documents ORSTOM 138, 13-45.

Giresse, P., Moguedet, G., 1982. Chronoséquences fluvio-marines de l'Holocène de l'estuaire du Kouilou et des colmatages côtiers voisins du Congo. In: Les rivages tropicaux-Mangroves d'Afrique et d'Asie, CEGET-CNRS, Travaux et Documents de Géographie Tropicale, Talence 39, 21-46;

Giresse, P., Maley, J., Kossoni, A., 2005. Sedimentary environmental changes and millennial climatic variability in a tropical shallow lake (Lake Ossa, Cameroon) during the Holocene. Palaeogeography, Palaeoclimatology, Palaeoecology 218, 257-285.

Hourcq, V., 1966. Le bassin côtier congolais. In: Reyre D (Ed.) Bassins sédimentaires du littoral africain. $1^{\mathrm{e}}$ partie: littoral atlantique, Association des Services Géologiques africains, Paris, pp. 197-206.

Jamet, R., 1967. Etude géologique d'une zone témoin dans la région deLoango. ORSTOM 
(IRD), Brazzaville.

Jamet, R. , Rieffel, J.M., 1976. Notice explicative 65. Carte Pédologique du Congo à 1/200.000, Feuille Pointe-Noire. Feuille Loubomo 2 cartes, on a large-scale reconnaissance map of the soils of Congo 65, $175 \mathrm{pp}$.

Kossoni. A., Giresse, P., 2010. Interaction of Holocene infilling processes between a tropical shallow lake system (Lake Ossa) and a nearby river system (Sanaga River) (South Cameroon). Journal of African Earth Sciences 56 : 1-14.

Maley, J., 1997. Middle to Late Holocene changes in tropical Africa and other continents: Paleomonsoon and sea surface temperature variations. In: Dalfes HN, Kukla G and Weiss $\mathrm{H}$ (eds.), Third millennium BC climate change and Old World collapse, NATO ASI Series, Global Environmental Change. Berlin, Springer-Verlag, pp. 611-640.

Maley J., 2012. The fragmentation of the African rain forests during the third millenium BP : palaeoenvironmental data and palaeoclimatic framework. Comparison with another previous event during the LGM. Colloque de l'Académie des Sciences, Paris, Coforchange. Poster 2-Holocene.

Massengo, A., 1970. Contribution à l'étude stratigraphique, sédimentologique et minéralogique de la Série plio-pléistocène du bassin côtier du Congo-Brazzaville. Doctoral thesis, Bordeaux University, $159 \mathrm{pp}$.

Ngomanda, A., Cheptow-Lusty, A., Makaya Mvoumou et al., 2005. Vegetation changes during the past 1300 years in western equatorial Africa : A high resolution pollen record from Lake Kamalete, Lope Reserve, Central Gabon. The Holocene 15(7), 1021

Nguetsop, F.V., Servant-Vildary, S., Servant, M., Roux, M., July, M. Long and short-time scale climatic variability in the last 5500 years in Africa according to modern and fossil diatoms from Lake Ossa (Western Cameroon), Global Planetary Change 72 (40), 356367.

Reynaud-Farrera, I., Maley, J., Wirrmann, D., 1996. Végétation et climat dans les forêts du sud ouest du Cameroun depuis 4770 ans BP: analyse pollinique des sédiments du lac Ossa, Compte Rendus Académie Sciences, Paris (IIA 322), 749-755.

Schwartz, D., 1985. Histoire d'un paysage: le lousséké. Paléoenvironnements quaternaires et podzolisation sur sables Batéké (quarante derniers millénaires, région de Brazzaville, R.P. Congo). Thèse Doctorat es Sciences Naturelles, Université de Nancy I, 211 pp.

Schwartz, D., Delibrias, G., Guillet, B., Lanfranchi, R., 1885. Datations par le ${ }^{14} \mathrm{C}$ d'alios humiques : âge Njilien (40.000-30.000 BP) de la podzolisation sur sable Batéké (République Populaire du Congo). Compte Rendus Académie Science 300, II, 17, 891894.

Schwartz, D., Guillet, B., Dechamps, R., 1990. Étude de deux flores forestières mi-holocènes (6000-3000 BP) et subactuelle (500 BP) conservées in situ sur le littoral ponténégrin 
(Congo). In: Lanfranchi R. and Schwartz D. (Eds) Paysages quaternaires de l'Afrique Centrale Atlantique. Collection Didactique, ORSTOM, Paris, pp 283-297.

Schwartz, D., Mariotti, A., Trouvé, C, Van Den Borg, K., Guillet, B., 1992. Étude des profils isotopiques ${ }^{13} \mathrm{C}$ et ${ }^{14} \mathrm{C}$ d'un sol ferrallitique sableux du littoral congolais. Implications sur la dynamique de la matière organique et l'histoire de la végétation Comptes Rendus Académie Sciences Paris 315 (II), 1411-1417.

Sebag, D., Disnar, J.R., Guillet, B. et al. , 2006. Monitoring organic matter dynamics in soil profiles by Rock-Eval pyrolysis: Bulk characterization and quantification of degradation. European Journal of Soil Science 57(3), 344-355.

Sebag, D., Debret, M., Makaya Mvoubou, Mabicka Obame, R., Ngomanda, A., Oslisly, R., Bentaleb, I., Disnar, J.R., Giresse, P., 2013. Coupled Rock-Eval pyrolysis and spectrophotometry for lacustrine sedimentary dynamics: Application for West Central African rainforests (Kamalété and Nguène lakes, Gabon). The Holocene 23(8), 11731183.

Sitou, L., Schwartz, D., Mietton, M., Tchikaya, J., 1996. Histoire et dynamique actuelle des cirques d'érosion du littoral d'Afrique centrale. Une étude de cas : les cirques du littoral ponténégrin (Congo). Symposium Dynamique à long terme des écosystèmes forestiers intertropicaux, CNRS-ORSTOM, Bondy, pp. 187-191.

Smith, B.N., Epstein, S., 1971. Two categories of ${ }^{13} \mathrm{C} /{ }^{12} \mathrm{C}$ ratios for higher plants. Plant Physiology 47, 380-384.

Stuiver, M., Reimer, P.J., 1993. Extended ${ }^{14} \mathrm{C}$ calibration data base and revised CALIB $3.0{ }^{14} \mathrm{C}$ age calibration program. Radiocarbon $35(21), 5-230$.

Vincens, A., Buchet, G., Elenga, H., Fournier, M., Martin, L., de Namur, C., Schwartz, D., Servant, M., Wirrmann, D., 1994. Changement majeur de la végétation du lac Sinnda (vallée du Niari, Sud-Congo) consécutif à l'assèchement climatique holocène supèrieur: apport de la palynologie. Compte Rendus Académie Science II A, Paris, II A (318), 1521-1526.

Vincens, A., Schwartz, D., Elenga, H., Reynaud-Farrera, I., Alexandre, A., Bertaux, J., Mariotti, A., Martin, L., Meunier, J.-D., Nguetsop, F., Servant-Vildary, S., Servant, M., Wirrmann, D., 1999. Forest response to climate changes in Atlantic Equatorial Africa during the last 4000 years BP and inheritance from the modern landscape. Journal Biogeography. 26, 879-885.

Vincens, A., Elenga, H., Schwartz, D., De Namur, C., Bertaux, J., Fournier, M., Dechamps, R., 2000. Histoire des écosystèmes forestiers du Sud-Congo depuis 6000 ans. In: Servant $\mathrm{M}$ and Servant-Vildary S (Eds), Dynamique à long terme des écosystèmes forestiers intertropicaux, Paris, UNESCO, pp 375-379. 


\section{Captions}

Fig. 1. Location of two studied sectors in Loango and Kivesso (blue arrows) on the largescale reconnaissance map of Congo soils (after Jamet and Rieffel, 1975) (1). Hydromorphic sandy soils of the coastal plain; (2). Organic or peaty soils developed on sands; (3). Sandy hydromorphic soils; (4). Sandy ferrallitic soils; (5). Immature soils on colluvium; (6). Wet area; 7. Ferrallitic soils on clayey sands of the Série des Cirques. N.B. Captions indicate the extent of the soil surfaces, this cannot correspond exactly to the vertical succession changes.

Fig. 2. Location of three sections in South Loango, North Loango 1 and 2 on the map below after Jamet and Rieffet (1975). The red arrows indicate the positions of the levels analysed by pyrolysis.

Fig. 3. Location of five sections in Kivesso (KV 3, KV4, KV5, KV6, KV7) on the map below after Jamet and Rieffet (1975). The red arrows indicate the positions of the levels analysed by pyrolysis.

Fig. 4. Diffractometric R.X analyses of the clay fraction of fine-grain levels of sections KVS4 and KBS2 assembled in a continuous section. Arrows indicate the analysed levels; the semi quantitative estimations concern the halloysite (Hal), TeOcTe minerals (especially illite and interstratified), smectites (poorly expressed) and goethite (Goeth).

Fig. 5. Scanning Electron Microscopy (SEM) photos from KVS 6 1.4-1.6 m, a. Micro-needles of goethite $(1 \mu \mathrm{m})$ coating the kaolinite pillars; b. Two generations of neoformed kaolinite in a cavity: 5 to $10 \mu \mathrm{m}$-large pile of pseudo-hexagonal tablets, then connection with aggregates of small tablets; c. Quartz surface in the process of dissolution, the geometry of the dissolution process is governed by the orthorombic system, kaolinitique aggregate on the left; from Loango Sud, $0-20 \mathrm{~cm}$, d. Neoformation of small silica clusters $\left(100 \% \mathrm{SiO}_{2}\right)$ on a quartz support affected by dissolution.

Fig. 6. Correlations of simplified logs of the Loango and Kivesso sector indicating positions of ${ }^{14} \mathrm{C}$ ages and the levels analysed by pyrolysis. 
Fig. 7. Rock Evall measurements. Relation between $\mathrm{S}_{3} \mathrm{CO}_{2}\left(\mathrm{CO}_{2}\right.$ released during thermal cracking of OM and siderite) and S2 measurements (thermal cracking of OM) from LoangoKivesso (black disks) compared with Lake Kamalété (small points and coloured disks) (Sebag et al., 2013)

Fig. 8. Characterisation of Loango-Kivesso OM based on Rock Evall parameters. (a). Relation TOCvsTpS2. 1. black disks: TOC $>16.5 \%$, 2. black circles: $9.4 \%<\mathrm{TOC}<16.5 \%$, and 3. red square: $\mathrm{TOC}<5 \%$. For comparison, points corresponding to the Loango-Kivesso measurements are placed on the analytical diagram of the KAM 01 Lake Kamalete coloured spots (Sebag et al., 2013); (b). Relation of HI vs OI on the Van Krevelen kerogene classification with Type 1 sapropelic-rich, Type 2 lipid-rich (phyto and zooplankton), Type 3 humic-rich (land plants). Black disks, circles, red squares and coloured spots have the same significance as 3a; green triangles are A1 or A2 horizons of the Pointe-Noire savanna (after Disnar et al., 2003).

Fig. 9. Synthetic graph of $\delta{ }^{13} \mathrm{C}$ according to the age deposits, analysed sediments were chosen in different sections of Loango and Kivesso.

Fig. 10. Palaeoenvironmental trend of the Loango-Kivesso coast. (1) $7000 \mathrm{yr}$ BP. The Holocene marine transgression culminated at the current zero, the edification of the first coastal sand dunes and fast isolation of the swamp depression, (2) 6000-3000 yr BP. 1-2 m of fresh ground water was retained by the oceanic water table (blue arrow), accumulation of the peaty layer resulting from forest development, formation of podzol accumulation horizons Bh, (3) 3000-1000 yr BP. Decrease of precipitations, filling trend of the swamps, the gley of hydromorphic soils were developing, local emersions were evidenced, (4) after 1000 BP and, here, after 500 BP. General trend to precipitation increase, then oceanic erosion of the sand barriers (green arrows).

Table 1. Radiocarbon chronology of the black organic deposit, calibrated using the Reimer et al. (2009) program. Calendric ages are given with 1 standard deviation. 
Table 2. $\mathrm{C}, \mathrm{N}$ and $\mathrm{C} / \mathrm{N}$ measurements of the black layers of KVS 2, KVS 4 and LN2 sections. C org analyses were restricted to the richest deposits in organic matter.

Table 3. Rok-Eval Pyrolysis analyses.

Table 4. Organic carbon $\delta{ }^{13} \mathrm{C}$ analyses. The ages are only indicative: the measures are obtained either on the same level or extrapolated according to the chronostratigraphic data. Reference measures of standard deviation obtained on a mud off the mouth of the Rhône River end in an order of magnitude of 0.307 , higher than the present analyses. Here, only two samples (KVS3-2, KVS7) are different because they include heterogenous organic matter (roots, bark and black debris). 


\begin{tabular}{|c|c|c|c|c|c|c|c|c|}
\hline Sample & Altitude $(\mathrm{m})$ & Latitude S & Longitude $\mathrm{E}$ & Matter & Lab. No. & $\begin{array}{l}\text { Conventional } \\
{ }^{14} \mathrm{C} \text { age (yrs BP) }\end{array}$ & $\begin{array}{l}\text { Calendric } \\
{ }^{14} \mathrm{C} \text { age (yrs BP) }\end{array}$ & $\begin{array}{l}68 \% \text { range } \\
\text { (cal yrs BP) }\end{array}$ \\
\hline LA2a b & +1.1 & $49399^{\prime} 49$ & $1147^{\prime} 53$ & muds & Poz-58970 & $4155 \pm 35$ & $4710 \pm 83$ & $4627-4793$ \\
\hline LA2a & +1.05 & $4399^{\prime} 49$ & $11^{\circ} 47^{\prime} 53$ & mud & Poz-58968 & $6000 \pm 40$ & $6846 \pm 50$ & 6795-6896 \\
\hline LA2a & +1.0 & $4399^{\prime} 49$ & $11^{\circ} 47^{\prime} 53$ & rods & Poz-58969 & $6255 \pm 35$ & $7205 \pm 36$ & $7169-7241$ \\
\hline LA4a & +3.40 & 4939'41 & $1148^{\prime} 18$ & muds & Poz-58971 & $2400 \pm 60$ & $2516 \pm 133$ & $2382-2649$ \\
\hline KVS6 & 0 & $4936^{\prime} 13$ & $11999^{\prime} 19$ & muds & Poz-58972 & $325 \pm 25$ & $387 \pm 52$ & $335-439$ \\
\hline KVS6 & +2.60 & $436^{\prime} 13$ & $11499^{\prime} 19$ & muds & Poz-58973 & $210 \pm 25$ & $223 \pm 68$ & $154-291$ \\
\hline KVS7 & 0 & $4936^{\prime} 23$ & 1149'23 & rods & Poz-58986 & $6190 \pm 35$ & $7093 \pm 59$ & 7033-7152 \\
\hline
\end{tabular}


ACCEPTED MANUSCRIPT

\begin{tabular}{|l|l|l|l|l|}
\hline Section & Height $(\mathrm{m})$ & C org $\%$ & $\mathrm{~N} \%$ & $\mathrm{C} / \mathrm{N}$ \\
\hline KVS 2 & 0.25 & 8.16 & 0.36 & 22.6 \\
\hline KSV 2 & 1.15 & 3.03 & 0.18 & 16.8 \\
\hline KSV 2 & 1.9 & 1.47 & 0.11 & 13.4 \\
\hline KSV 2 & 3.1 & 0.63 & 0.06 & 10.3 \\
\hline KSV 2 & 3.8 & 0.27 & 0.03 & 8.9 \\
\hline KSV 4 & 1.32 & 17 & 0.59 & 28.8 \\
\hline KSV 4 & 2.7 & 5 & 0.4 & 12.5 \\
\hline KSV 4 & 3.25 & 0.54 & 0.06 & 9 \\
\hline LN 2 & 2.9 & 0.29 & 0.04 & 7.2 \\
\hline LN 2 & 3.43 & 0.45 & 0.04 & 10 \\
\hline LN 2 & 4.1 & 0.33 & 0.037 & 8.9 \\
\hline LN2 & 4.48 & 0.19 & 0.025 & 7.44 \\
\hline
\end{tabular}




\begin{tabular}{|l|l|l|l|l|l|l|l|l|l|l|}
\hline Sample & Facies & Bark debris & Age cal BP & HI & Ol & TOC & S2 & S3 CO2 & TPK S2 & Tmax (iC) \\
\hline KVS6 15 & humiferous horizon & & 223 & 305 & 54 & 3.41 & 10.41 & 1.02 & 441 & 399 \\
\hline KSV4 16 & black mud & & c.a. 200 & 315 & 67 & 9.39 & 29.56 & 3.32 & 457 & 415 \\
\hline KSV4 2 & laminated black mud & $* \star *$ & c.a. 350 & 321 & 49 & 10.25 & 32.92 & 2.73 & 423 & 381 \\
\hline KSV2 2a & laminated peaty mud & $* \star *$ & c.a. 350 & 280 & 137 & 16.51 & 46.2 & 4.26 & 448 & 406 \\
\hline KSV6 1 & laminated mud & ${ }^{* *}$ & 387 & 103 & 74 & 1.86 & 1.92 & 0.43 & 418 & 376 \\
\hline La N 2b & accumulation horizon & ${ }^{*}$ & 6846 & 307 & 1 & 0.99 & 3.04 & 0.23 & 471 & 429 \\
\hline La N 2a & peat & ${ }^{* \star \star *}$ & 7205 & 281 & 46 & 23.29 & 65.36 & 4.48 & 421 & 379 \\
\hline KSV7 2 & peaty silt & ${ }^{*}$ & 7093 & 224 & 177 & 5.11 & 11.47 & 2.1 & 440 & 398 \\
\hline
\end{tabular}




\begin{tabular}{|c|c|c|c|c|c|c|}
\hline Site & sample & Height (m) & Delta 13C & Mean value & Ecart-type & $\begin{array}{c}\text { Approximate } \\
\text { age }\end{array}$ \\
\hline \multirow[t]{14}{*}{ Kivesso } & KVS1-1 & +1.5 & $-28.05,-28.24,-28.19$ & -28.16 & 0.19 & 400 yr BP \\
\hline & KVS1-15 & +4.6 & $-17.24,-16.82$ & -17.03 & 0.36 & 100 yr BP \\
\hline & KVS2-2 & +0.2 & $-28,-27.98$ & -27.99 & 0.02 & 500 yr BP \\
\hline & KVS-23 & +4 & $-15.9,-15.89$ & -15.90 & 0.01 & $100 \mathrm{yr}$ BP \\
\hline & KVS3-2 & +1 & $-26.61,-28.72,-28.56$ & -28.63 & 2.11 & 400 yr BP \\
\hline & KVS3-4 & +1.4 & $-27.77,-27.67,-28.09$ & -27.84 & 0.42 & 300 yr BP \\
\hline & KVS4-2 & +1 & $-28.1,-28.3,-28.1$ & -28.17 & 0.2 & 400 yr BP \\
\hline & KVS4-16a & +2.10 & $-21.54,-21.49,-21.14$ & -21.39 & 0.4 & 350 yr BP \\
\hline & KSV4-16b & +2.65 & $-25.54,-25.66$ & -25.6 & 0.12 & 300 yr BP \\
\hline & KVS6-T01 & +0.1 & $-27.45,-27.63,27.54$ & -27.54 & 0.18 & 387 yr BP \\
\hline & KVS6-T11 & +0.55 & $-15.28,15.02$ & -15.15 & 0.26 & 300 yr BP \\
\hline & KVS7-2 & +0.2 & $-27.54,-27.45,-27.45$ & -27.48 & 0.09 & 7093 yr BP \\
\hline & KVS7 & +0.4 & $-28.12,-26.91,-24.4$ & -27.95 & 3.72 & $\leq 7093$ yr BP \\
\hline & & & & +1 & & \\
\hline Matoumbi nord & MTN 2a & +2.30 & $-26.56,-26.42$ & -26.49 & 0.14 & $400 \mathrm{BP}$ \\
\hline & & & & & & \\
\hline \multirow[t]{5}{*}{ Loango } & LS-2c & +0.2 & $-27.57,-22.6,-22.73$ & -24.3 & 0.16 & 4710 \\
\hline & LS-2b & +0.2 & $-21.16,-21.19,21.32$ & -21.22 & 0.16 & 6846 \\
\hline & LA-2a & +0.2 & $-28.19,-28.21,-28.25$ & -28.22 & 0.06 & 7205 \\
\hline & LN1-4a & +3 & $-21.44,-21.14,-21.25$ & -21.28 & 0.06 & $\leq 2500$ yr BP \\
\hline & LN1-4c & +3 & $-17.48,-16.45,-15.83$ & -16.18 & 1.29 & $\leq 2500$ yr BP \\
\hline
\end{tabular}




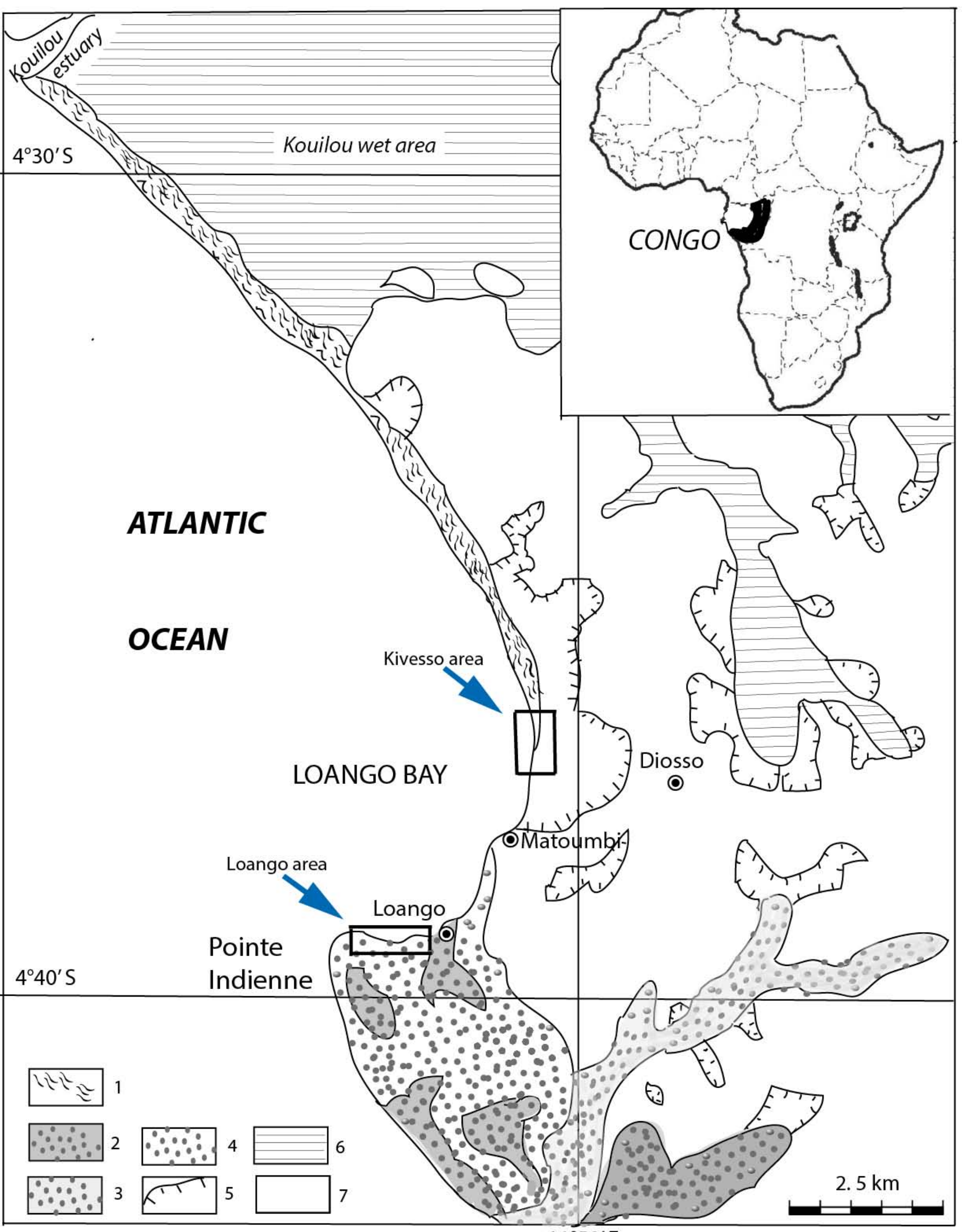




\section{KVS 4}

KVS 2

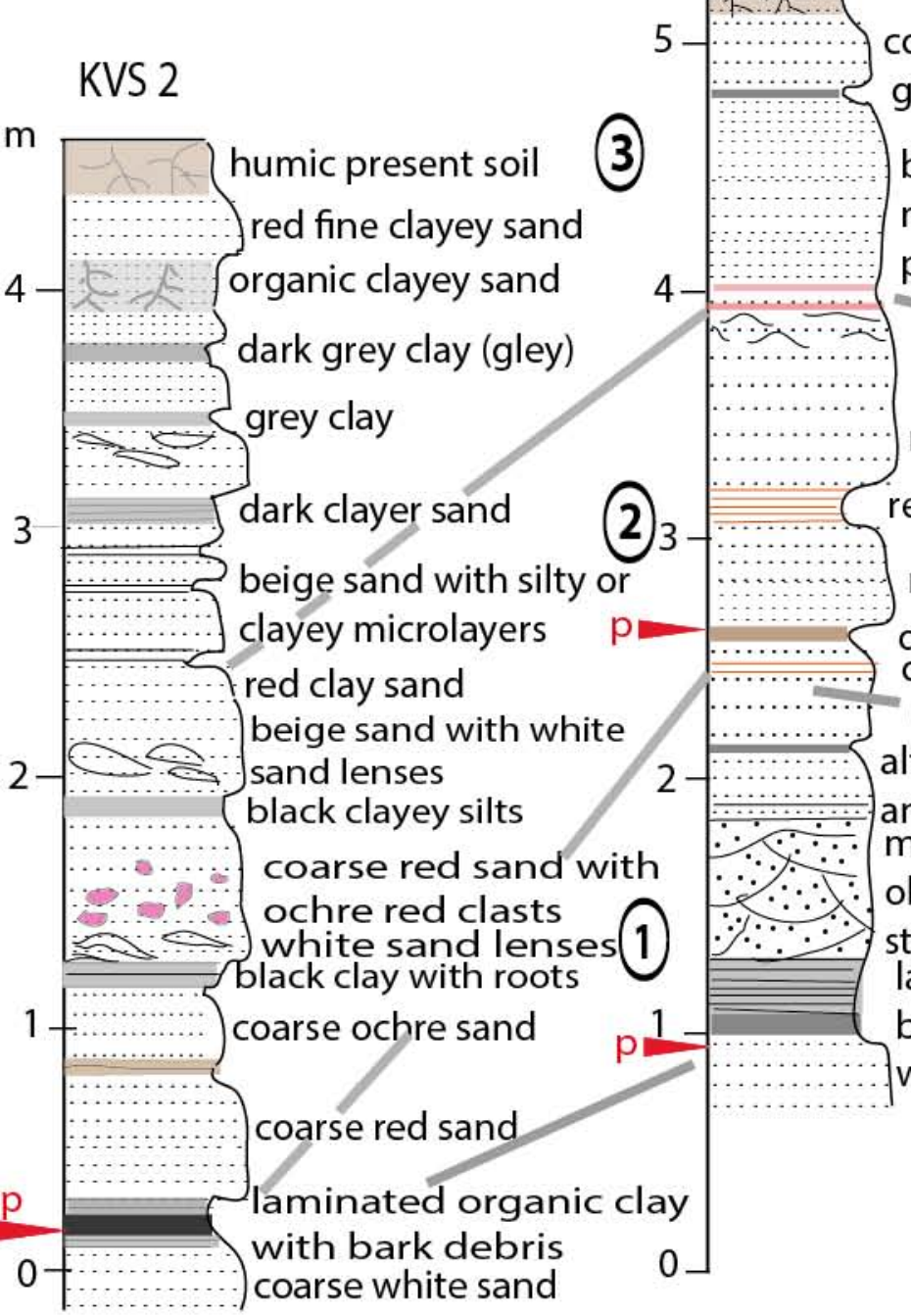

humic present soil

coarse white sand

grey layer

beige sand with red microlayers in the lower part

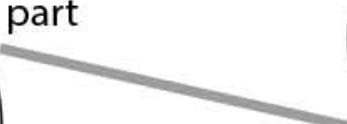

medium red ochre sand $\mathrm{p}=(\ldots \ldots \ldots \ldots \ldots)$

(3)

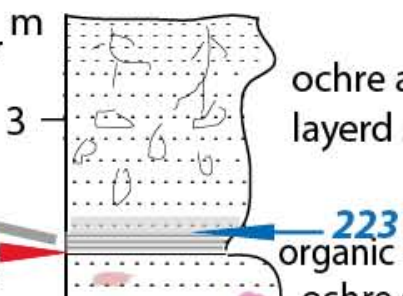
(a............. organic clayey sand with

red fine sand

fine sand

ochre organic clayey layer
ochre sandy clay
ochre fine sand
alternance of grey silty $\quad 1$

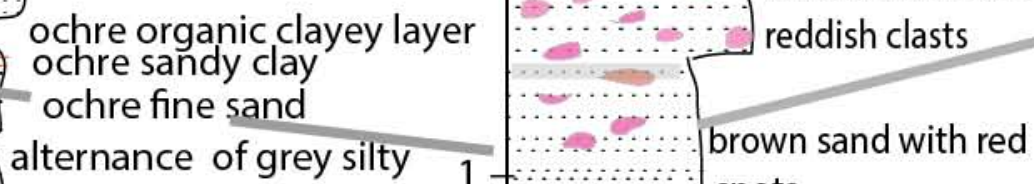

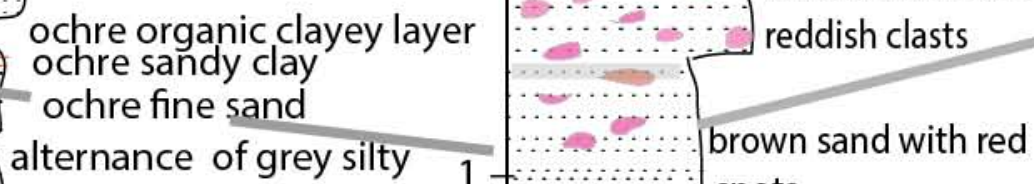
and sandy layers medium white sand with oblique oblique
stratification
laminated organic clay

black debris white medium sand

(2)
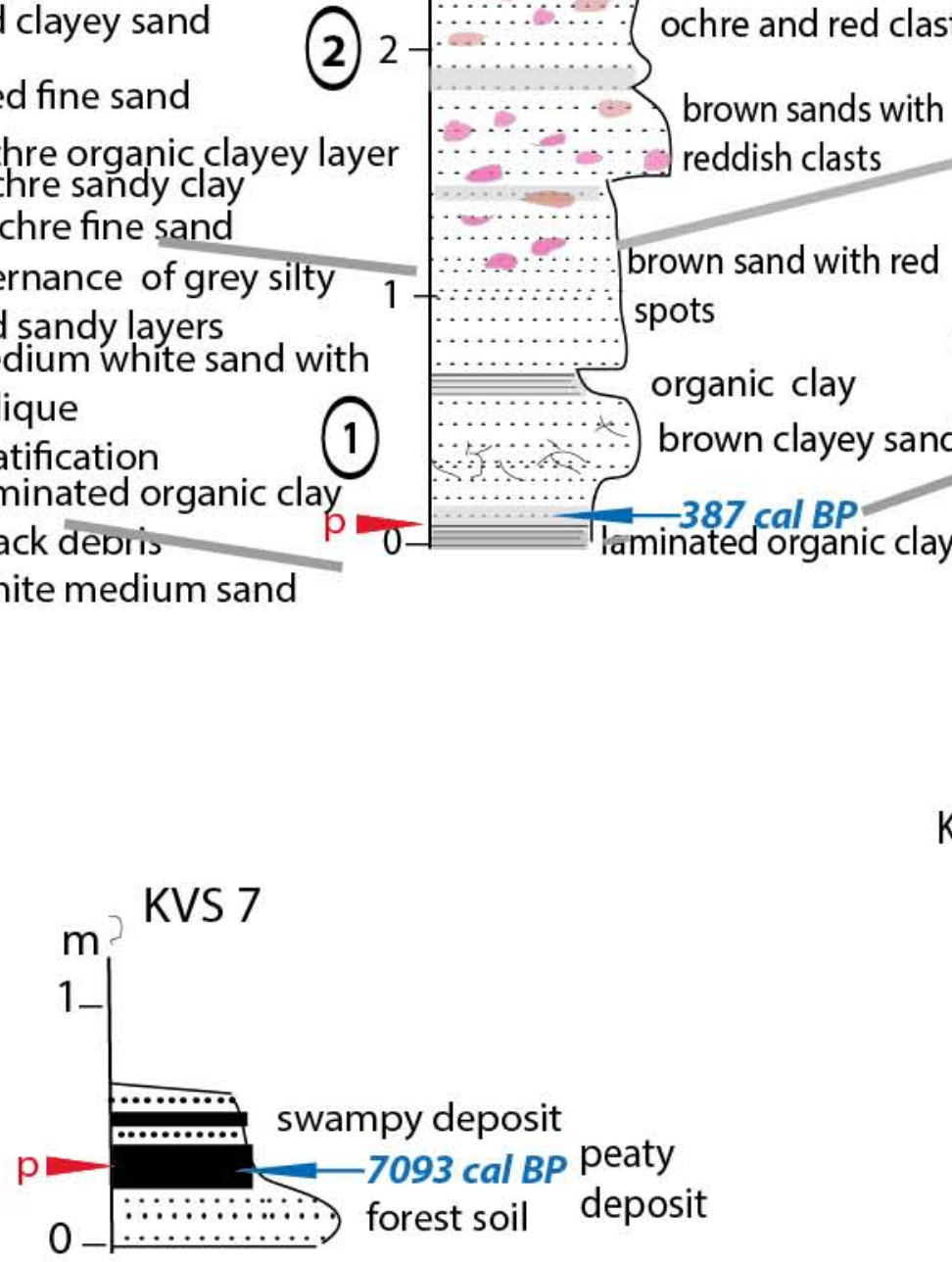
organic clay
KVS 6

$\because x)$ humic present soil white coarse sand

bioturbated organic sand white coarse sand

ochre medium sand with reddish clasts

ochre sand with red clasts grey fine sand with pink clasts organic clayey layer

(1)

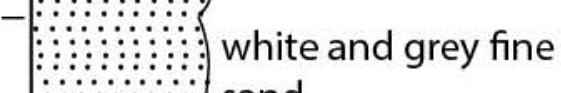
$0=1$ laminated organic clay 1$]$ organic laminated clay

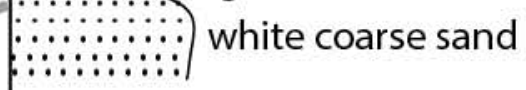

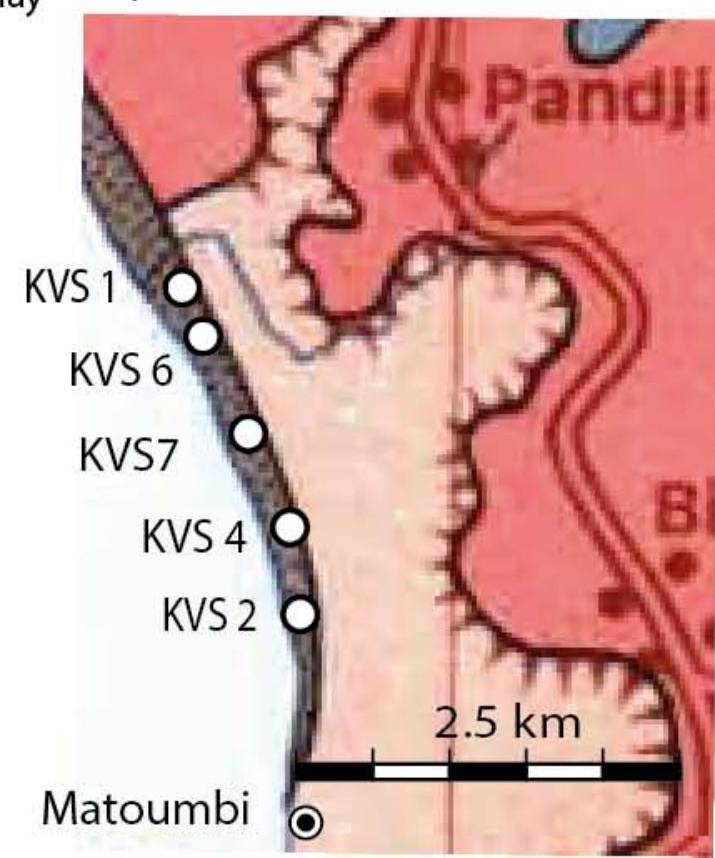




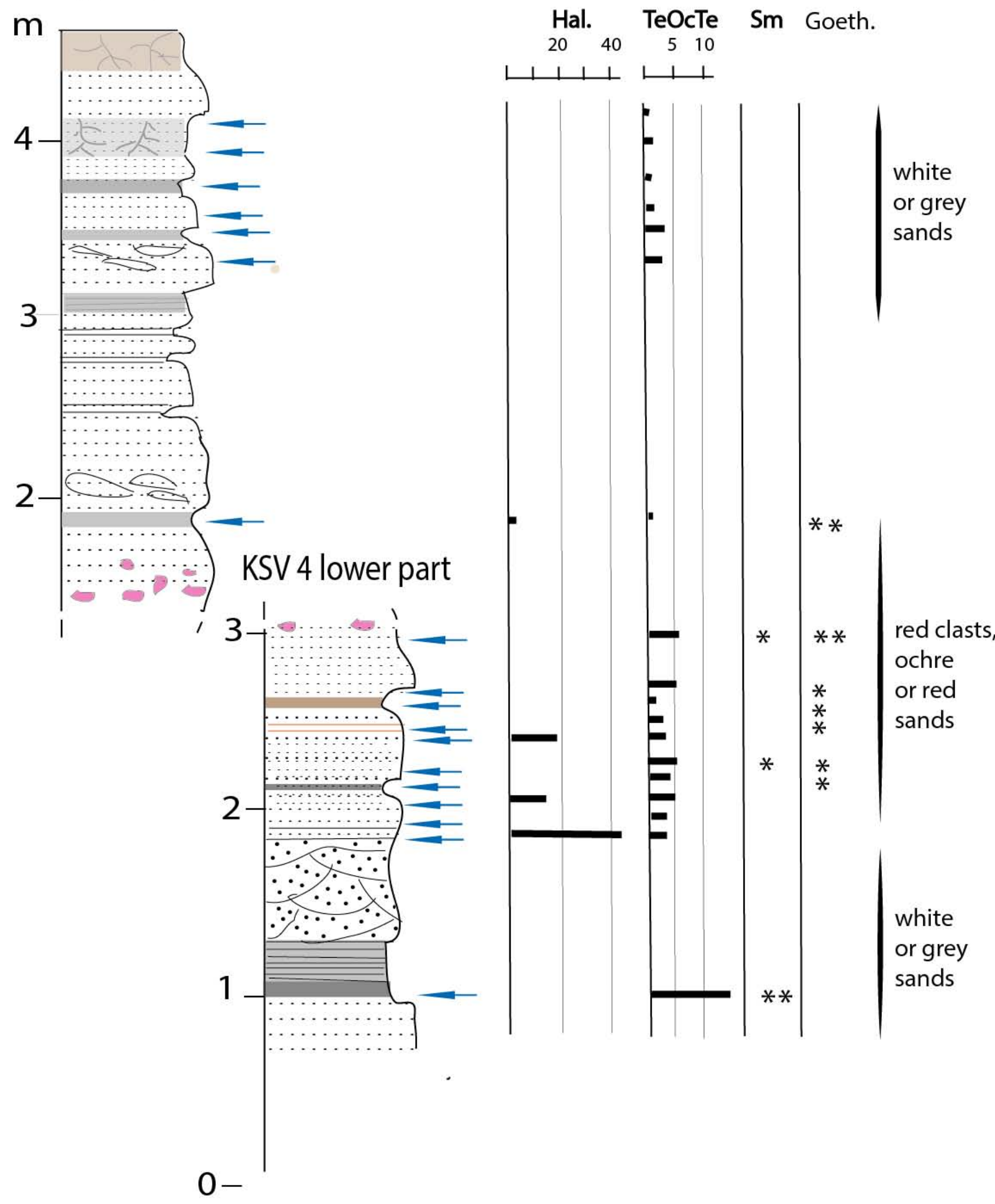




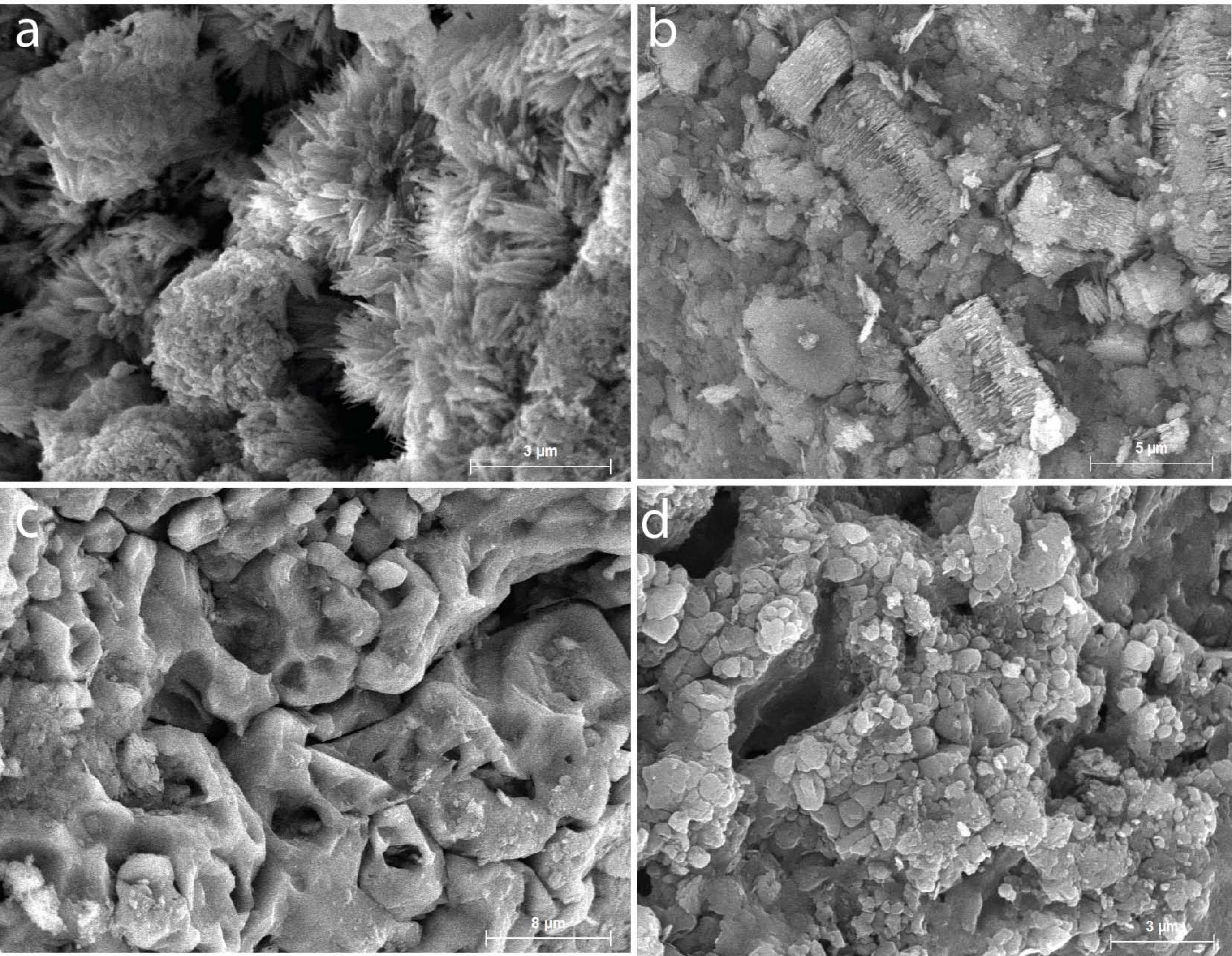




\section{KIVESSO area}

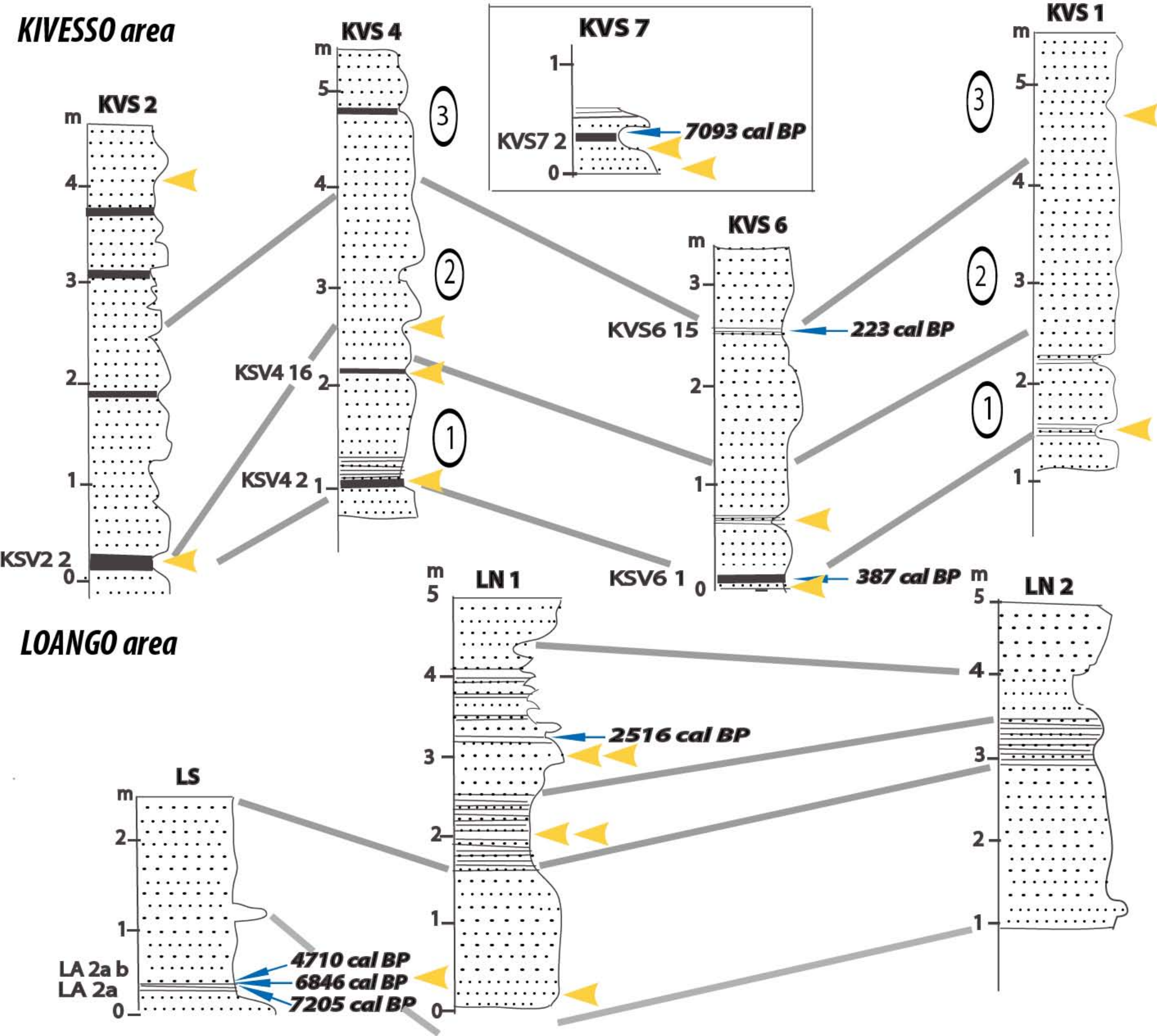

KVS 7

KVS 1
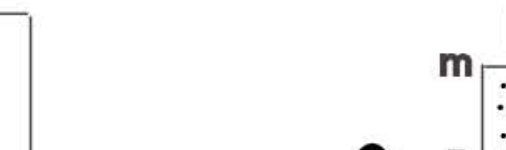

LOANGO area 


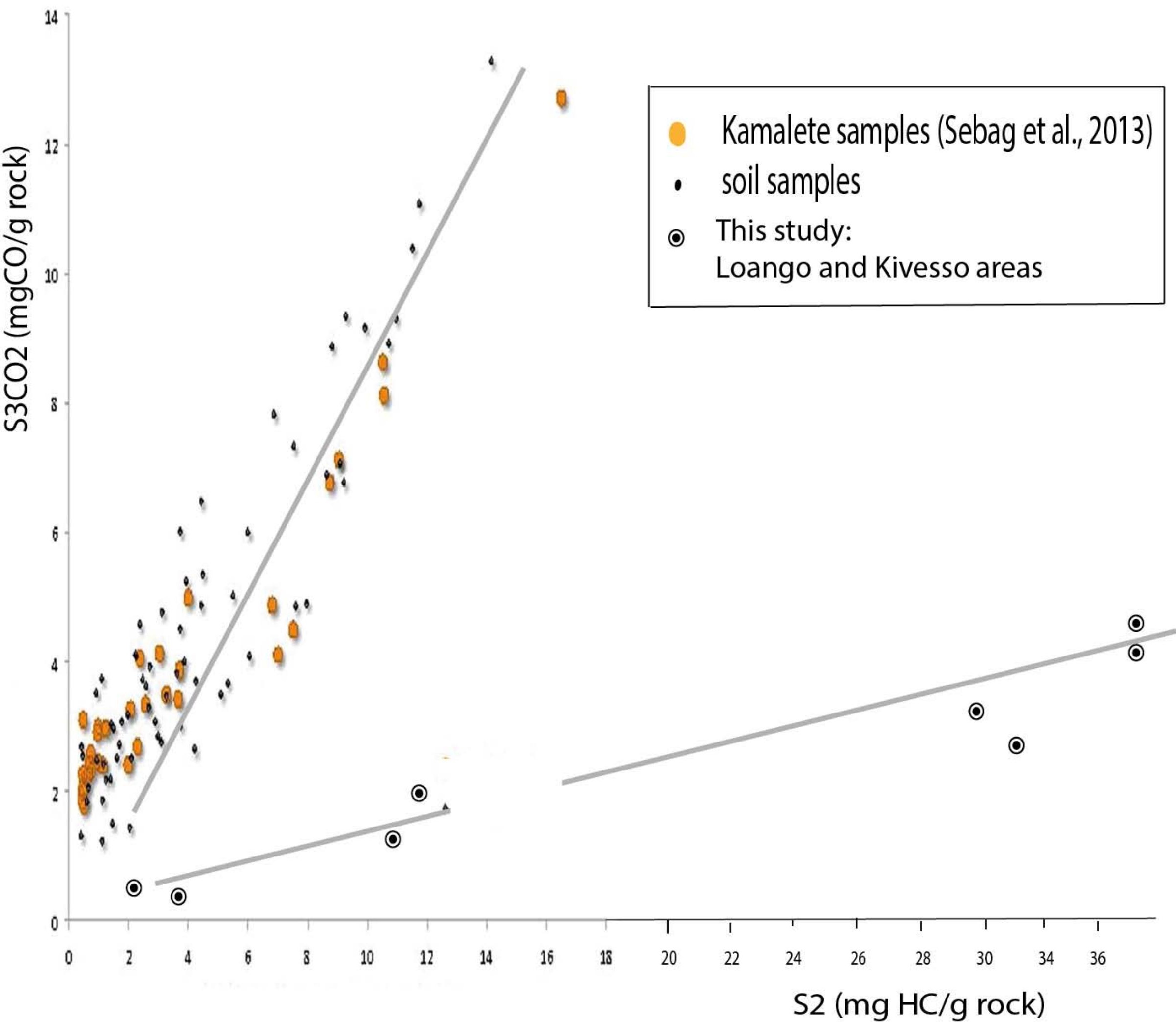



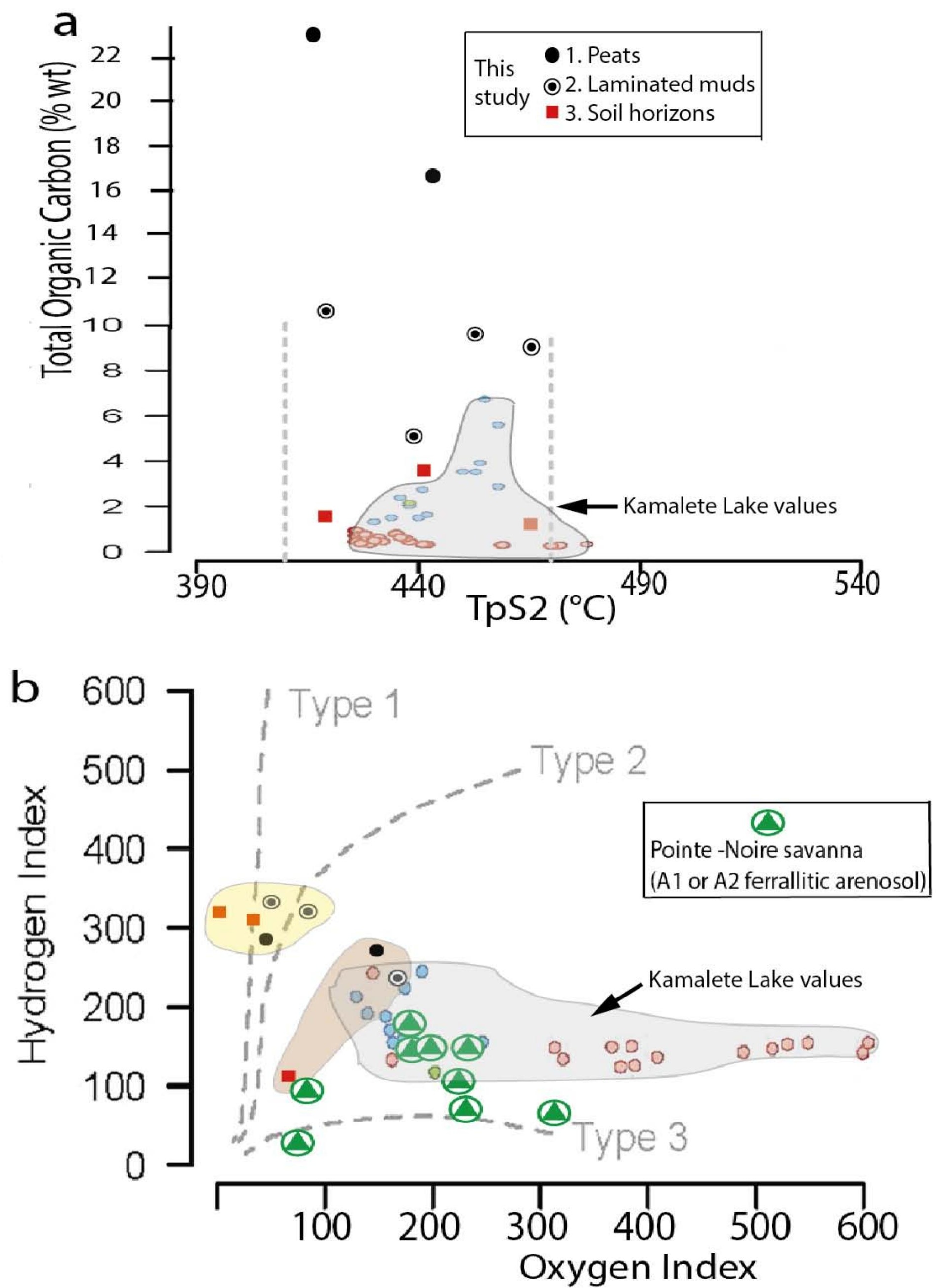
$\delta^{13} \mathrm{C}(\% \circ)$

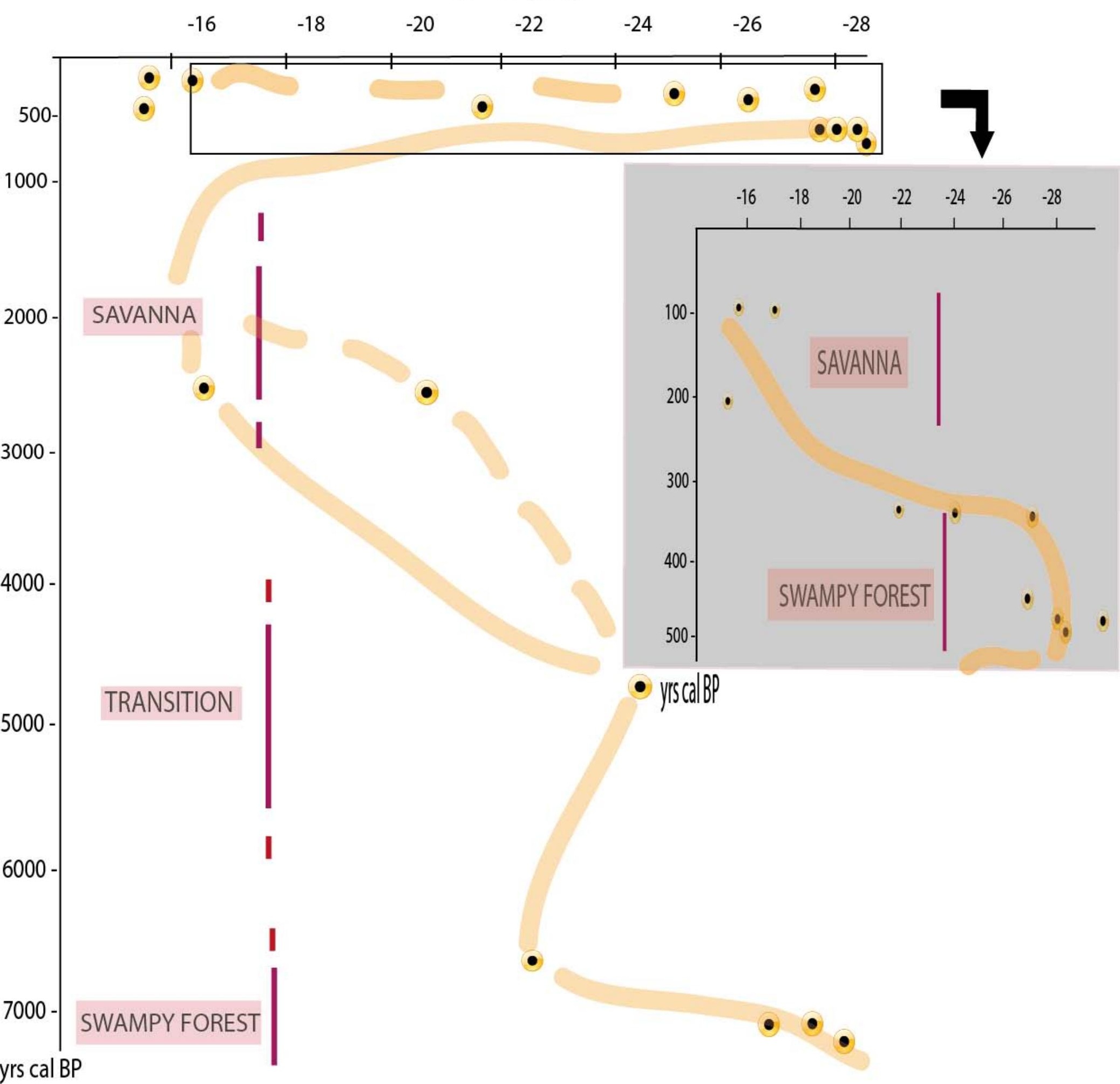



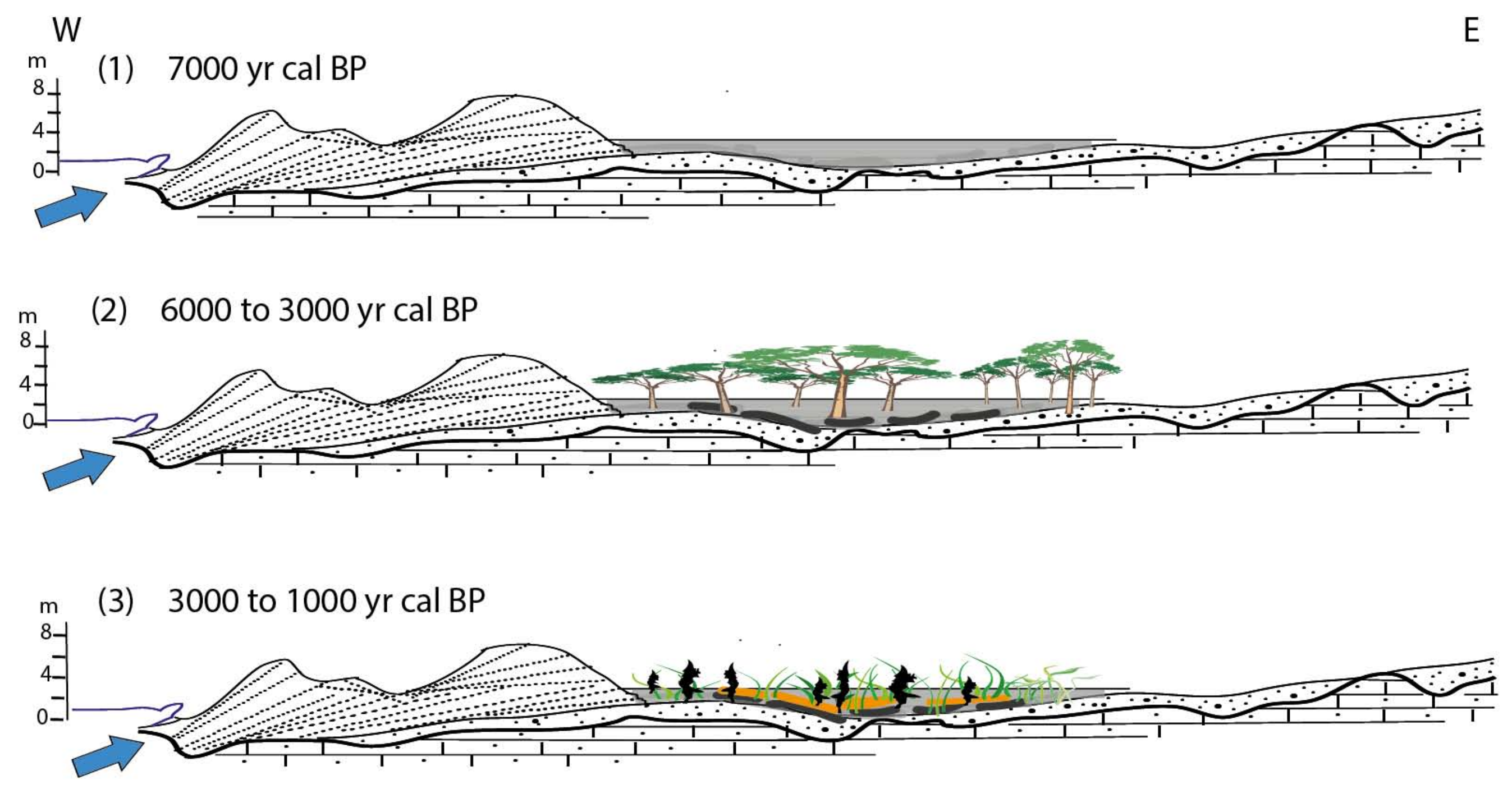

(4) after $500 \mathrm{yr}$ cal BP

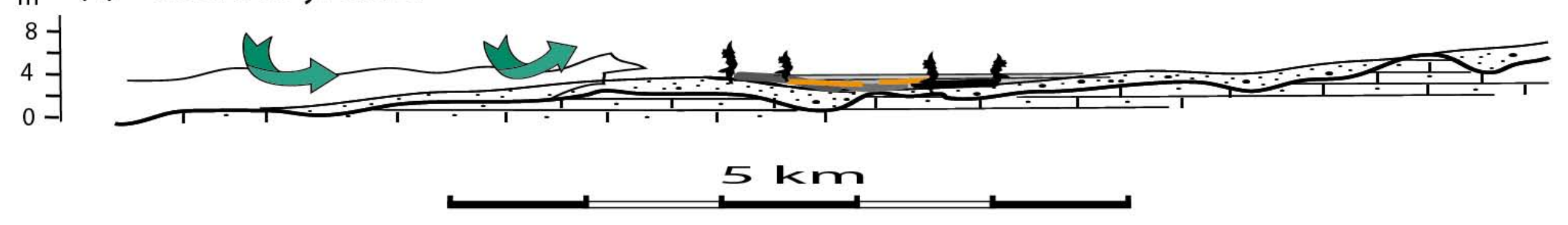


From 7-6000 yr cal BP, a dense ombrophile and hydromorphic forest staid sheltered from any brackish influence

The emersive trend of $3000-2000 \mathrm{yr}$ BP is indicated by the passage from a vast forest swamp with a water-body of some meters deep to a wet zone

The $\delta{ }^{13} \mathrm{C}$ values of older peats dated ca. $7000 \mathrm{yr}$ cal BP are - 28 to $-26 \%$, typical of a C3 origin.

At $2500 \mathrm{yr}$ cal BP.the ca. $-16 \%$ value indicates the greatest opening of the cover

During the last two centuries an ultimate drier trend has been attested by $\delta^{13} \mathrm{C}$ ratio. 